Review

\title{
The exploration of Hashimoto's Thyroiditis related miscarriage for better treatment modalities
}

\author{
Yu Min, Xing Wang, Hang Chen, Guobing Yin ${ }^{\bowtie}$ \\ Department of Breast and Thyroid Surgery, The Second Affiliated Hospital of Chongqing Medical University, No.74, Linjiang Rd, Yuzhong Dist, Chongqing \\ 404100, China. \\ $\square$ Corresponding author: Prof. Guobing Yin, Ph.D., Department of Breast and Thyroid Surgery, The Second Affiliated Hospital of Chongqing Medical \\ University, No.74, Linjiang Rd, Yuzhong Dist, Chongqing, 404100, People's Republic of China. Tel.: 86+15823267119; E-mail: yinguobing@cqmu.edu.cn. \\ (C) The author(s). This is an open access article distributed under the terms of the Creative Commons Attribution License (https://creativecommons.org/licenses/by/4.0/). \\ See http:/ /ivyspring.com/terms for full terms and conditions.
}

Received: 2020.05.13; Accepted: 2020.08.21; Published: 2020.08.29

\begin{abstract}
Hashimoto's thyroiditis (HT) is the most prevalent autoimmune thyroid disease (ATD) worldwide and is strongly associated with miscarriage and even recurrent miscarriage (RM). Moreover, with a deepening understanding, emerging evidence has shown that immune dysfunctions caused by HT conditions, including imbalanced subsets of CD4+ T-helper cells, B regulatory (Breg) cells, high expression levels of CD56dim natural killer (NK) cells, and cytokines, possibly play an important role in impairing maternal tolerance to the fetus. In recent years, unprecedented progress has been made in recognizing the specific changes in immune cells and molecules in patients with HT, which will be helpful in exploring the mechanism of HT-related miscarriage. Based on these findings, research investigating some potentially more effective treatments, such as selenium (Se), vitamin D3, and intravenous immunoglobulin (IVIG), has been well developed over the past few years. In this review, we highlight some of the latest advances in the possible immunological pathogenesis of HT-related miscarriage and focus on the efficacies of treatments that have been widely introduced to clinical trials or practice described in the most recent literature.
\end{abstract}

Key words: Hashimoto's thyroiditis; autoimmune disease; miscarriage; immune system; intravenous immunoglobulin; levothyroxine

\section{Introduction}

Hashimoto's thyroiditis (HT), which is also known as chronic lymphocytic thyroiditis (CLT), is currently the most prevalent autoimmune thyroid disease (ATD) [1]. However, the etiopathogenesis is still incompletely defined. HT causes chronic inflammation of the thyroid tissues, and hypothyroidism in approximately $20-30 \%$ of patients, especially in the female population [2-4]. Previous research has shown that HT is an independent risk factor for the occurrence and development of papillary thyroid carcinoma (PTC). Additionally, the complications of HT have a greater long-term negative impact on pregnant women.

Currently, miscarriage occurs in $8-15 \%$ of clinically recognized pregnancies and approximately $30 \%$ of all pregnancies in recent epidemiological investigations $[5,6]$, and chromosomal abnormalities account for approximately $50 \%$ of fetal losses in the first 8-15 weeks of gestation [7]. However, while the miscarriage rate has slightly decreased in recent years $[5,6]$, unexplained miscarriage and even recurrent miscarriage (RM), which is defined as two consecutive spontaneous losses or three or more spontaneous losses, severely impact the physical and mental health of the female population [8]. With a deepening understanding of the maternal and fetal immune response, unexplained miscarriage is closely related to an abnormally activated maternal immune system.

Although HT is regarded as one of organspecific autoimmune diseases (ADs), numerous clinical studies have confirmed that similar to other ADs, HT plays a vital role in women's miscarriage and even RM [9-13]. With the development of cellular and molecular immunology, accumulating studies have found that not only hypothyroidism but also immune system disorders [14] caused by HT conditions are involved in the pathogenesis of 
adverse pregnancy outcomes [15-18]. During a healthy pregnancy, the upregulation of regulatory $\mathrm{T}$ (Treg) cells and T-helper type 2 (Th2) cells represent a major maternal adaptation that helps with embryo implantation and the maintenance of pregnancy [19-21]. However, under HT conditions, the expression levels of proinflammatory cytokines are upregulated, while anti-inflammatory factors are downregulated [15, 17]. Due to the complex mechanisms underlying HT-related miscarriage, which are still under exploration, especially the pathway involved in the HT-mediated abnormally activated immune response, treatment decisions mainly focus on avoiding hypothyroidism and rebalancing the function of the immune system. However, the efficacies of L-thyroxine (L-T4) substitution and other immunomodulatory drugs are inconsistent in recent research [10, 22-25].

The purpose of this review is to summarize the specific changes in immune cells and cytokines under HT conditions, which can provide a basis for the investigation of more novel immunotherapies for women with HT-related miscarriage. In addition, we discuss the efficacies of treatments that have been widely introduced to clinical practice described in the most recent literature.

\section{HT and miscarriage}

Currently, HT is the most prevalent organspecific $\mathrm{AD}$, with an insidious onset, and can ultimately cause hypothyroidism in nearly $20 \%-30 \%$ of patients [1, 2]. The histological characteristics of HT include atrophy of follicular cells, diffuse lymphocyte infiltration in thyroid tissue, goiter, and fibrosis. In a

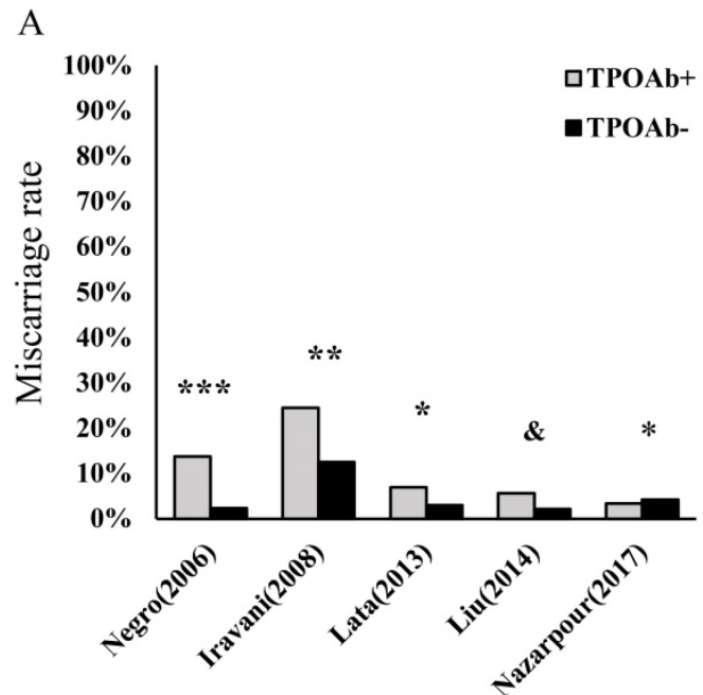

recent large-scale epidemiological survey involving 78,470 participants in China [26], the prevalence of positive thyroid globulin antibody (TgAb) and thyroid peroxidase antibody (TPOAb) were $9.7 \%$ and $10.19 \%$, respectively, with a dominance of females. Thus, HT is gradually becoming a noticeable problem in women's health, including pregnancy in women of childbearing age $[11,27,28]$. Maternal hypothyroidism has been shown to be significantly associated with miscarriage, preterm birth, and growth restriction. In addition, this condition can affect hormonal changes, resulting in decreased plasma concentrations of both total testosterone and estradiol (E2) [29, 30]. Consequently, L-T4 supplementation is the most important initial treatment among patients with HT to avoid overt hypothyroidism, which may help reduce the prevalence of adverse pregnancy outcomes [30-32]. In contrast, numerous women with HT have been observed to be in $\mathrm{SH}$, which is the precursor state to hypothyroidism. Similar to patients with overt hypothyroidism, these euthyroid patients with HT have higher rates of miscarriage and even RM than healthy control (Figure 1A). However, the efficacy of L-T4 supplementation among euthyroid women applied to prevent miscarriage and preterm birth induced by HT in recent research is inconsistent (Figure 1B). Notably, with the extended exploration of HT in recent years, an abnormally activated proinflammatory state of the immune system is found in these patients [14, 17, 18, 33-35]. Therefore, these findings enrich our knowledge of HT-related miscarriage, especially in euthyroid women.

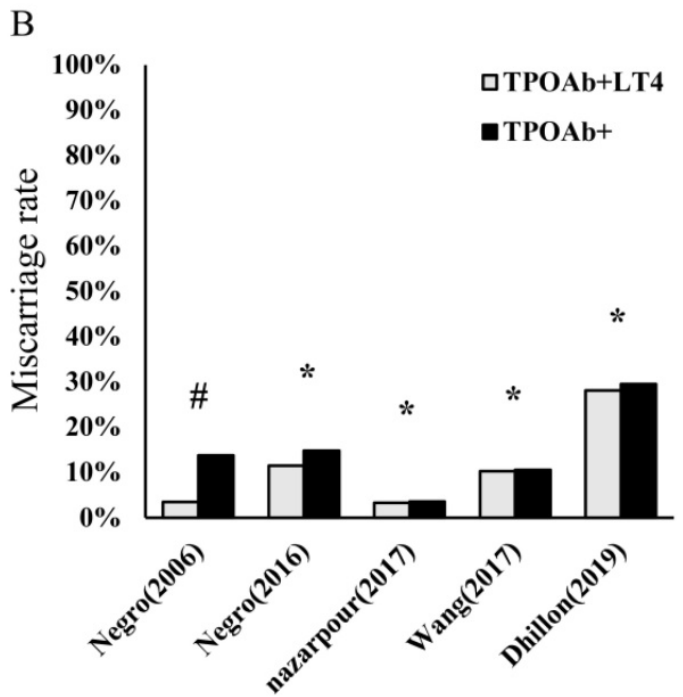

Figure 1. Hashimoto's thyroiditis (HT) is an important risk factor in miscarriage and even recurrent miscarriage (RM). However, the efficacies of L-T4 supplementation are still debatable. (A). The percentage of miscarriage in thyroid peroxidase antibody-positive (TPOAb+) pregnancies euthyroid women and health controls (TPOAb-); ${ }^{* * *} p<0.0001$ and ${ }^{* *} p<0.001$ compared to control groups; ${ }^{*} p=$ no statistical significance (NS) and ${ }^{*} p=0.002$ compared to controls $[11,12,24,185,186] ;(B)$. The percentage of miscarriage among euthyroid women with TPOAb+ who received levothyroxine treatment $\left(\right.$ TPOAb+LT4) and had no treatment or placebo $\left(\right.$ TPOAb+); $\#<<0.01$ and ${ }^{*} p=N S$ compared to controls $[10,22,24,25,185]$. 


\section{Immune system disorders}

As women increasingly exhibit unexplained reproduction failure $[5,36,37]$, especially under HT conditions [9-12], many researchers have attempted to reveal the possible underlying mechanisms and facilitate the development of new and better treatment approaches, particularly for subpopulations of women with RM. Previous research has found that women with thyroid autoimmunity had a higher prevalence of the copresence of non-organ-specific autoantibodies, which could add to the risk of adverse pregnancy outcomes [38, 39]. Similarly, a recently published study reported a higher prevalence of RM in women with HT and nonendocrine autoimmune disorders (NEADs), such as atrophic gastritis and connective tissue diseases, than women with isolated HT $(p<0.0001)$ [40]. Therefore, the phenomenon of a higher risk of miscarriage in women with HT and concurrent NEADs is helpful for understanding the pathogenesis of HT-related miscarriage and suggests that patients can simultaneously benefit from effective treatments for NEADs before conceiving. Regarding $\mathrm{HT}$, although the circulating TPOAb or TgAb level has repeatedly been reported to be an independent risk factor determining miscarriage, the association between different titers of these antibodies and the risk ratio of miscarriage is still debatable [40-43]. Indeed, importantly, immune system disorders, including the upregulation of proinflammatory cells and downregulation of anti-inflammatory cells, are observed in the peripheral blood (PB) of patients with HT (Table 1). Thus, anti-thyroid antibodies are more likely markers of a potentially wider autoimmune imbalance. Additionally, some important cytokines, such as interleukin (IL)-10 and transforming growth factor-beta (TGF- $\beta$ ), are expressed at lower levels in maternal-fetal immune tolerance than in pregnant women without HT. Some researchers suggest that similar to other immune diseases, HT could share similar mechanisms in inducing pregnancy loss [16, $18,44]$. The circulating TPOAb level $[45,46]$, abnormal immune system activation, an imbalance in subsets of $\mathrm{T}$ cells and Breg cells and a strong cytotoxic effect of natural killer (NK) cells [17, 18, 47] are possible mechanisms underlying the progression of HTrelated miscarriage (Figure 2).

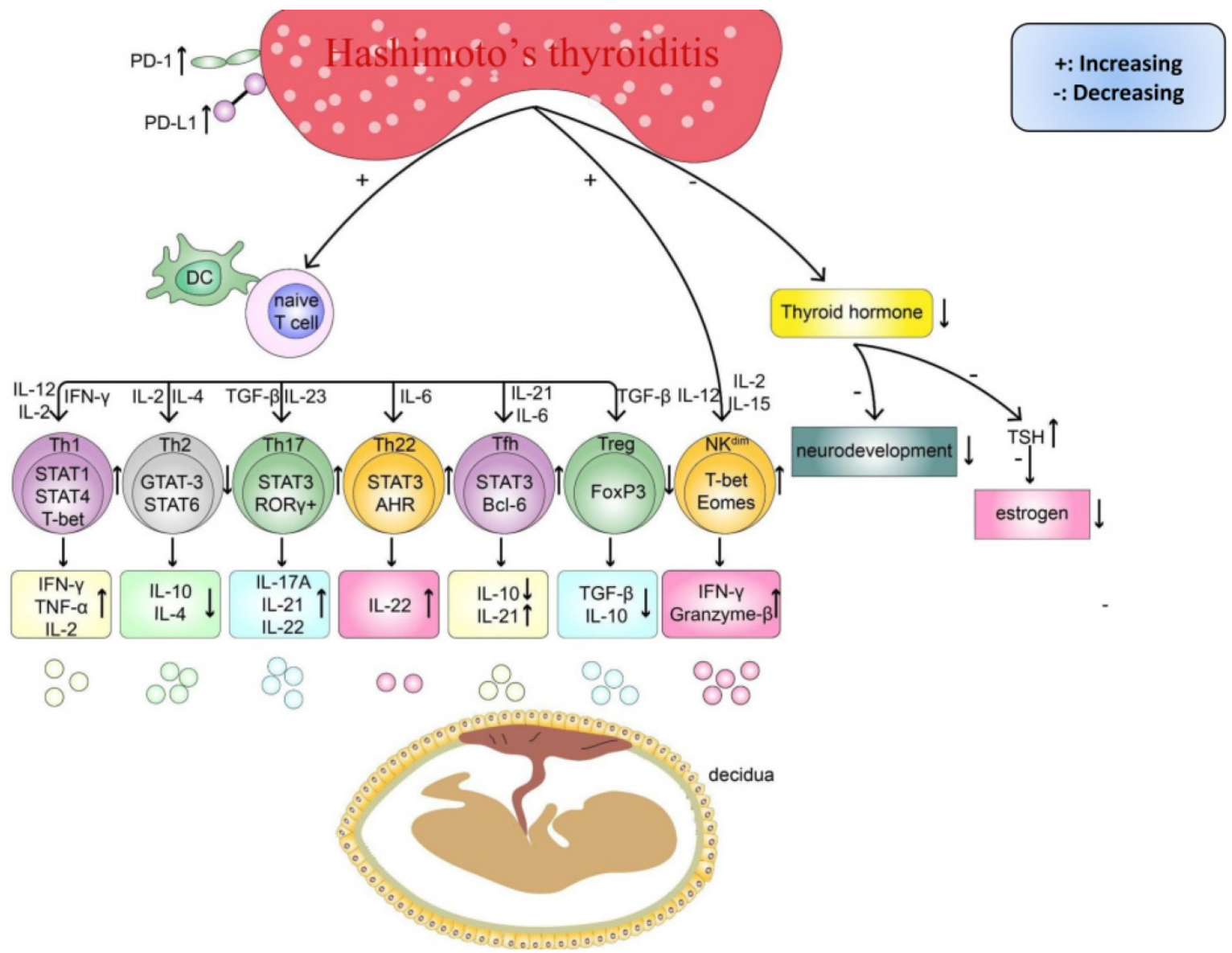

Figure 2. There are existing endocrine and immune disorders in HT women, which can impair pregnancy outcomes. Firstly, the imbalanced differentiation of naïve CD4+T cells, such as the abnormal increased Th cells (Th1, Th17, Th22, Tfh) and cytokines (IL-2, IL-6, IL-12, IL-15, IL-17A, IL-21, IL-22, IL-23, IFN-y, TNF-a), and decreased Th cells (Th2, Treg) and cytokines(IL-4, IL-10, TGF- $\beta$ ). Secondly, abnormal activated NKdim cell and its cytokines (IFN-y, Granzyme B). Finally, the insufficient thyroid hormone caused by chronic inflammatory damage in the thyroid can delay the fetus's neurodevelopment and decrease the level of estrogen. 
Table 1. Expression levels of immune cells and cytokines in Hashimoto's thyroiditis

\begin{tabular}{|c|c|c|c|}
\hline Components & $\begin{array}{l}\text { Expression } \\
\text { (U/D/I) }\end{array}$ & Function and correlation with miscarriage and RM & Reference \\
\hline \multicolumn{4}{|l|}{ Cells } \\
\hline Th1 & $\mathrm{U}$ & $\begin{array}{l}\text { Proinflammatory; The low level of Th1 cell expression has a positive effect on placenta formation, but high } \\
\text { expression of cytotoxic factors levels, including IFN-ץ and TNF-a, will impair immune tolerance at the } \\
\text { maternal-fetal interface during pregnancy. }\end{array}$ & {$[58,62,151]$} \\
\hline Th2 & $\mathrm{D}$ & $\begin{array}{l}\text { Anti-inflammatory; Th2 cells can significantly inhibit the activation of T cells and promote immune tolerance at } \\
\text { the maternal-fetal interface. }\end{array}$ & {$[16,152]$} \\
\hline Th1/Th2 & $\mathrm{U}$ & $\begin{array}{l}\text { The ratio of Th1/Th2 reflects the functional balance between proinflammatory and anti-inflammatory cytokines } \\
\text { in the human immune system. The higher this ratio, the more severe inflammatory reaction is, which can impair } \\
\text { the process of pregnancy. }\end{array}$ & {$[16,58,59]$} \\
\hline Th17 & $\mathrm{U}$ & $\begin{array}{l}\text { Proinflammatory; The Th17 cells' responses are often overwhelming in HT, which may cause the immune system } \\
\text { to shift towards an inflammatory profile and impair the immune tolerance at the maternal-fetal interface during } \\
\text { pregnancy. }\end{array}$ & {$[50,61]$} \\
\hline Th22 & $\mathrm{U}$ & $\begin{array}{l}\text { Immunoregulatory; The Th22 cell can regulate the chronic inflammatory reaction, which is crucial for embryo } \\
\text { implantation and the success of pregnancy. }\end{array}$ & {$[51,61]$} \\
\hline Tfh & $\mathrm{U}$ & $\begin{array}{l}\text { Immunoregulatory; Memory Tfh cells have a central role in the regulation of the adaptive immune response. A } \\
\text { higher number of Tfh is observed in RM women than controls. }\end{array}$ & {$[15,34,153]$} \\
\hline Treg & $\mathrm{D}$ & $\begin{array}{l}\text { Treg cells can inhibit effector immunity, contain inflammation, and support maternal vascular adaptations. } \\
\text { Insufficient Treg numbers or inadequate functional competence are implicated in RM }\end{array}$ & {$[20,33,154]$} \\
\hline Breg & $\mathrm{U} / \mathrm{I}$ & $\begin{array}{l}\text { Anti-inflammatory; Breg can both suppress the pro-inflammatory response, mostly by the production of IL- } 10 \\
\text { cytokine, and enhance the activity of Treg cells. But dysfunctions of Breg cells were determined in PB of HT } \\
\text { patients. Whether it could further impair the immune tolerance at the maternal-fetal interface during pregnancy } \\
\text { need more research to evaluate. }\end{array}$ & {$[65-67,69,71]$} \\
\hline NK & $\mathrm{U}$ & $\begin{array}{l}\text { Proinflammatory; dNK cells, one of NK cell subsets, are important to placenta formation in early pregnancy. But } \\
\text { abnormal activated NKdim cells can cause miscarriage and even RM by cytotoxic activities. }\end{array}$ & {$[73,75,144]$} \\
\hline \multicolumn{4}{|l|}{ Cytokines } \\
\hline 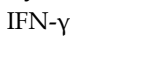 & $\mathrm{U}$ & $\begin{array}{l}\text { Proinflammatory; By increasing the expression of MHC-I and MHC-II and stimulating NK and Th1 inflammatory } \\
\text { responses, abnormal IFN- } \gamma \text { responses can induce the miscarriage and RM. }\end{array}$ & {$[4,155,156]$} \\
\hline TNF- $\mathrm{a}$ & $\mathrm{U}$ & $\begin{array}{l}\text { Proinflammatory; TNF- } \alpha \text {, same as TNF- } \beta \text {, has the cytotoxic effects, but whether TNF- } \alpha \text { is associated with } \\
\text { miscarriage needs more exploration. }\end{array}$ & {$[157,158]$} \\
\hline IL-2 & $\mathrm{U}$ & $\begin{array}{l}\text { Proinflammatory; It promotes the polarization of Th1 cells and immune responses, but whether it can impair the } \\
\text { pregnancy need further research. }\end{array}$ & {$[159,160]$} \\
\hline IL-4 & $\mathrm{D}$ & $\begin{array}{l}\text { Anti-inflammatory; IL- } 4 \text { is one of the important anti-inflammatory cytokines in regulating immune tolerance at } \\
\text { the maternal-fetus interface. }\end{array}$ & {$[55,56,58,63]$} \\
\hline IL-10 & $\mathrm{D}$ & $\begin{array}{l}\text { Anti-inflammatory; IL-10 is one anti-inflammatory cytokine with important immunoregulatory functions and } \\
\text { plays an important role in a successful pregnancy. }\end{array}$ & {$[54,66,161]$} \\
\hline IL-17 & $\mathrm{U}$ & Proinflammatory; It was observed increasing in healthy pregnancy but not in spontaneous abortion. & {$[162-165]$} \\
\hline IL-21 & $\mathrm{U}$ & $\begin{array}{l}\text { Proinflammatory; IL- } 21 \text { can induce the Th17 differentiation, inhibit the Treg development, and modulation of } \\
\text { antibody responses of B lymphocytes. But further research needs to investigate the correlation between IL-21 and } \\
\text { miscarriage. }\end{array}$ & [166-168] \\
\hline IL-22 & $\mathrm{U}$ & $\begin{array}{l}\text { Anti-inflammatory; High expression levels of IL- } 22 \text { potentially represent the reparative processes of organisms, } \\
\text { which may be a biomarker of placental dysfunction caused by chronic inflammation. }\end{array}$ & [169-172] \\
\hline IL-23 & $\mathrm{U}$ & $\begin{array}{l}\text { Proinflammatory; It plays an important role in early pregnancy, while the abnormally increased expression level } \\
\text { of IL-23 can induce a miscarriage. }\end{array}$ & [173-175] \\
\hline Granzyme B & $\mathrm{U}$ & Cytotoxic effect; high levels of Granzyme B may impair the embryonic development. & [176] \\
\hline TGF- $\beta$ & $\mathrm{D} / \mathrm{I}$ & $\begin{array}{l}\text { Anti-inflammatory; The expression level of the TGF- } \beta \text { is related to hormone levels during pregnancy, which is } \\
\text { important to maintain pregnancy. }\end{array}$ & {$[177-180]$} \\
\hline \multicolumn{4}{|c|}{ 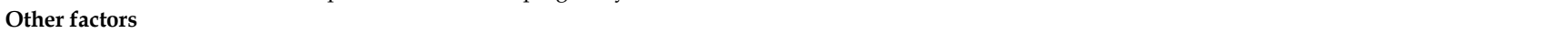 } \\
\hline PD-1/PD-L1 & $\mathrm{U}$ & $\begin{array}{l}\text { Anti-inflammatory; High expression levels of PD-1 and PD-L1 in the uterine decidua can inhibit the activity of the } \\
\text { inflammatory cells, which are critical for the success of the pregnancy. However, it does not seem that increased } \\
\text { expression levels of PD-1 and PD-L1 in HT tissues are beneficial to decrease the risk of miscarriage. }\end{array}$ & {$[79,181,182]$} \\
\hline FoxP3 & $\mathrm{D} / \mathrm{I}$ & $\begin{array}{l}\text { Anti-inflammatory gene; the low expression and splice variants of FoxP3 induce Treg function defect and further } \\
\text { impair the expression level of CD } 4^{+} \mathrm{CD} 25^{+} \mathrm{FoxP}^{+} \text {cells, which may increase the risk of miscarriage. }\end{array}$ & {$[33,88,89,183]$} \\
\hline Tim-3 & tD & $\begin{array}{l}\text { Anti-inflammatory gene; combined with PD-1, Tim-3 signaling can enhance the expression levels of } \\
\text { immunosuppressive cells to promote the maternal-fetal immune tolerance. }\end{array}$ & {$[21,82-84,184]$} \\
\hline
\end{tabular}

tD: Lower expression of Tim-3 than controls was observed in Graves' disease patients with thyroid-associated ophthalmopathy but not in HT patients.

\section{CD4+ T-helper cells}

Similar to other ADs, HT is often accompanied by immune dysfunction, especially imbalanced subsets of $\mathrm{CD}^{+}$T-helper cells. Consequently, the unregulated expression of cytokines secreted by different T-helper cell subsets may contribute to the progression of HT and its complications. For instance, numerous studies revealed higher levels of T-helper type 1 (Th1) and T-helper type 17 (Th17) cells but lower Th2 and Treg cells in the PB of women with HT $[44,48]$.

For successful implantation and fetal development during pregnancy, the proportions of naïve $\mathrm{CD} 4^{+} \mathrm{T}$-helper cell subsets, which are mainly differentiated into Th1 cells, Th2 cells, Th17 cells, and Treg cells, are significantly correlated with immune tolerance at the maternal-fetal interface $[19,48,49]$. On the one hand, cytokines, including interferon-gamma $(\mathrm{INF}-\gamma)$, tumor necrosis factor-alpha (TNF-a), and 
IL-17, secreted by Th1 and Th17 cells [50-52] can promote trophoblast differentiation and fusion during placenta formation. In addition, controlled, mild inflammation on the maternal-fetal interface and extravillous trophoblast cells (EVTs) play a crucial role in proper remodeling and invasion of maternal spiral arteries in the uterine decidua $[52,53]$. On the other hand, during pregnancy, cytokines, including TGF- $\beta$, IL-4, and IL-10, secreted by Th2 and Treg cells can regulate maternal-fetal immune tolerance for better embryo implantation and development [54-58]. Moreover, the balance of $\mathrm{CD}^{+}{ }^{+} \mathrm{T}$ cell subsets, especially the Th1/Th2 ratio on the maternal-fetal interface, is closely related to reproductive success $[16,59]$. Therefore, continuous high expression levels of proinflammatory cytokines and low expression levels of anti-inflammatory cytokines in $\mathrm{T}$ cell subsets in PB [60-62] can weaken immune tolerance at the maternal-fetal interface and the progression of thyroiditis (Figure 2). Regarding euthyroid patients with HT with (or without) NEADs, notably, an inspiring study by Santaguida et al. [63] measured the intracellular Th1 and Th2 distinctive cytokine levels (IL-2 in Th1 and IL-4 in Th2) in these patients. Correspondingly, a significant increase in Th1 cells was observed in these patients with NEADs, which was consistent with the changes in Th1 in patients with mild or severe hypothyroidism with HT [58]. However, the main difference was observed in the percentages of Th2 cells between the patients with isolated HT and patients with NEADs. As these two studies discovered, a reduced percentage of Th2 cells was detected in patients with HT, and this percentage was significantly positively correlated with the disease severity [58, 63]. In contrast, most patients with concurrent NEADs had a significantly increased percentage of Th2 cells and a lower Th1/Th2 ratio than the patients with isolated HT (1.78 vs. 3.8). Thus, detecting the Th1/Th2 ratio in women with HT before and during pregnancy is warranted to discover potential systemic ADs and predict the risk of adverse pregnancy outcomes; however, further research is needed to prove this possible relationship.

\section{$B$ regulatory cells}

Traditionally, B cells are involved in the pathogenesis of ADs (such as systemic lupus erythematosus, SLE) through antigen (Ag)-specific autoantibody production [64]. However, with the deepening of clinical and basic research, the negative regulatory effects on cellular immune responses and inflammation have been determined in Breg cells, which constitute a small subset of B cells (Figure 3). Numerous cytokines produced by Breg cell subsets have been determined, and IL-10 is the most widely studied [65-68]. A recently published comprehensive review noted that IL-10 secreted by Breg cells could independently not only suppress Th1 and enhance Th2 polarization but also inhibit IFN- $\gamma$ and TNF- $\alpha$ responses in vitro [69]. However, this effect was weakened in patients with NEADs $[68,70]$. In a study conducted by Flores-Borja et al. [68], the efficacies of $\mathrm{CD} 19^{+} \mathrm{CD} 24^{\text {hi }} \mathrm{CD} 38^{\text {hi }}$ Breg cells in the polarization of $\mathrm{CD}^{+}{ }^{+} \mathrm{T}$-helper cells were compared between patients with active rheumatoid arthritis (RA) and healthy controls. As the authors determined, in the healthy patients, CD19 ${ }^{+} \mathrm{CD} 24^{\text {hiC }} \mathrm{CD} 38^{\text {hi }}$ Breg cells could inhibit naïve $\mathrm{T}$ cell differentiation into Th1 and Th17 cells and convert $\mathrm{CD}^{+} \mathrm{CD}^{2} 5^{-} \mathrm{T}$ cells into regulatory $\mathrm{T}$ cells (Tregs) by the production of IL-10. However, the number and function of $\mathrm{CD} 19^{+} \mathrm{CD} 24^{\mathrm{hi}} \mathrm{CD} 38^{\mathrm{hi}}$ Breg cells were reduced and impaired in the patients with active RA, respectively, such that these cells could only maintain the capacity to inhibit Th1 cell differentiation [68]. The phenomenon of increased expression levels but impaired negative-regulation functions of Breg cells was also observed in patients with HT $[65,66]$. Notably, Santaguida et al. [65] found a similar percentage of unstimulated Breg and Breg memory cells in patients with HT and healthy controls, while euthyroid patients with HT showed an increased proportion of functional Breg cells $\left(\mathrm{CD} 19^{+} \mathrm{CD} 24^{\text {hi CD}} 38^{\mathrm{hi}} \mathrm{IL}-10^{+}\right.$Breg cells). Moreover, these authors also demonstrated an increased number of Breg cells with reduced functional parts in patients with HT and concurrent NEADs compared with patients with isolated HT. This insightful discovery and their latest research concerning this topic [40] suggest that more attention should be paid to HT women with NEADs because these women may have more frequent and severe immune system disorders and a higher risk of miscarriage and even RM. However, to date, the literature concerning the functions of Breg cells in immune tolerance in pregnancy is limited to only one study, which revealed a beneficial impact in successful delivery [71]. In addition, whether the impaired functions of Breg cells in HT are related to adverse pregnancy outcomes requires more extensive research.

\section{NK cells}

The different subtypes of NK cells, including CD16+CD56 dim (90\%), CD16- CD56 bright, and CD162, play a central role in resisting viruses and inhibiting the early spread of tumors by secreting cytokines, such as IFN- $\gamma$, and mediating antibody-dependent cell-mediated cytotoxicity (ADCC) [72]. However, some studies demonstrated that the frequency of CD56 dim NK cells in the PB of euthyroid women with HT was significantly higher than that in healthy 
controls [15, 18, 73]. This finding indicates that abnormally activated NK cells are possibly involved in the progression of HT and subsequent complications. The current study finds that CD56 bright $\mathrm{CD}^{2} 5^{+} \mathrm{NK}$ cells, which are regarded as decidual NK (dNK) cells and constitute $70 \%$ of decidual immune cells during a normal pregnancy, are considered to play a pivotal role in trophoblast invasion and uterine spiral artery remodeling and exert a regulating effect at the maternal-fetal interface [74]. However, instead of dNK cells, the high levels of $\mathrm{CD} 16^{+} \mathrm{CD} 56^{\mathrm{dim}} \mathrm{NK}$ cells derived from other body parts through blood circulation can impair maternal tolerance to the fetus. As shown in most recent studies, the percentage of peripheral $\mathrm{CD}^{-} \mathrm{CD}^{-} 6^{+} \mathrm{CD} 16^{+} \mathrm{NK}^{\text {dim }}$ cells in women with RM is higher than that in healthy controls $(p<$ 0.0001) [75]. Thus, altogether, these results imply that the abnormal activation of CD56 dim NK cells under HT conditions may share the same cytotoxic effects on the fetus during gestation and lead to early miscarriage in women.

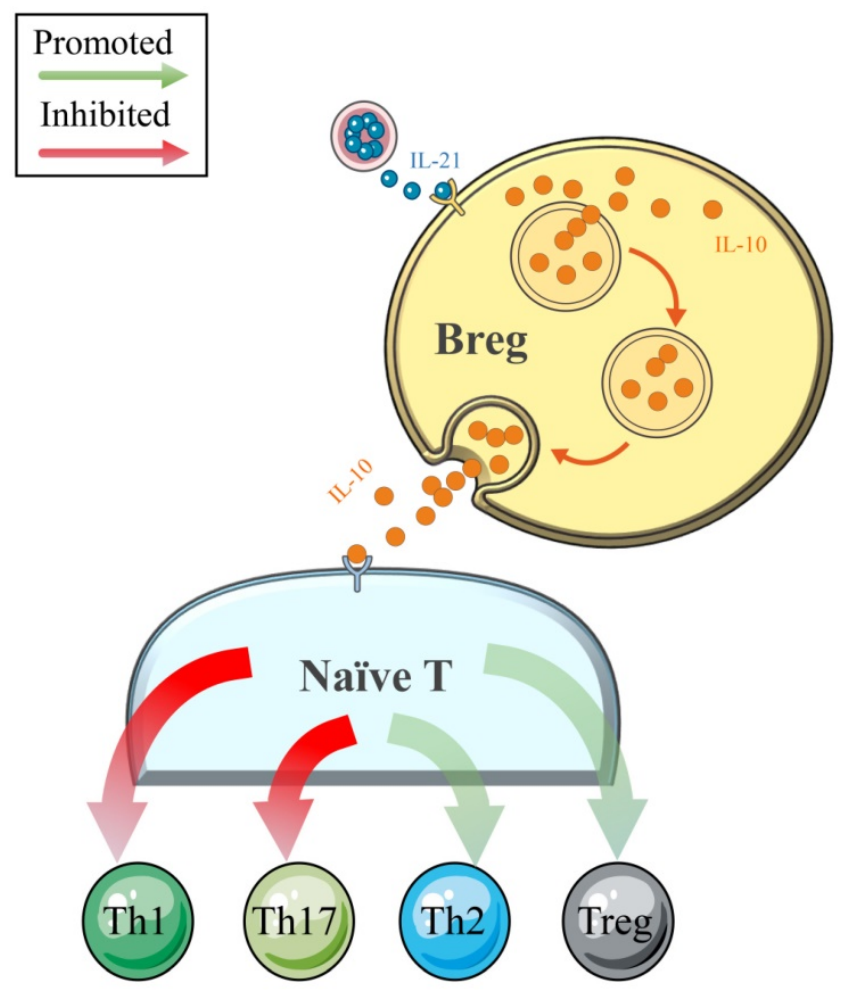

Figure 3. In healthy individuals, Breg cells play an important role in maintaining the crucial balance between the pool of Tregs/Th1/Th2/Th17 populations by the release of IL-10. The negative regulatory effects of Breg cells thereby limit inflammatory responses and subsequent tissue damage.

\section{PD-1}

Although programmed cell death-1 (PD-1) is widely identified as an essential target that promotes the invasion and metastasis of tumors [76-78], it also plays an indispensable role in maintaining maternal- fetal tolerance when coexisting with $\mathrm{T}$ cell immunoglobulin mucin-3 (Tim-3). For example, in an animalbased experiment [21], the augmented coexpression of PD-1 and Tim-3 on $\mathrm{CD}^{+} \mathrm{T}$ cells promoted the predominant production of Th2 cells, and the increased secretion of Th2-type cytokines, such as IL-4 and IL-10, contributed to maintaining normal pregnancy. Although many studies have revealed that PD-1 and programmed cell death-ligand 1 (PD-L1) are highly expressed in HT tissues [34, 48, 79, 80] regardless of whether differentiated thyroid carcinoma (DTC) coexists, it seems to be the response to HT conditions in the immune microenvironment. However, the poor suppressive function of the moderating effect is unable to modify the inflammatory phenomenon in the thyroid and accidentally promotes the metastasis of DTC $[80,81]$. To date, whether a difference exists in the PD-1 expression level on the maternal-fetal interface between women with HT and non-HT women during early pregnancy, which may have potential clinical applications for predicting the occurrence of miscarriage, still remains inconclusive.

\section{Tim-3}

Regarding Tim-3, which is an important inhibitory molecule, numerous studies have demonstrated its essential role in maintaining early pregnancy [82-84]. Tim-3 plays a positive role in the establishment and maintenance of maternal-fetal tolerance by regulating maternal decidual $\mathrm{CD}^{+} \mathrm{T}$ $\left(\mathrm{dCD} 8^{+} \mathrm{T}\right)$ cell responses and the subpopulation of $\mathrm{NK}$ cells. In one study [84], a distinct NK cell subpopulation, i.e., Tim-3+ NK cells, was identified to display immunosuppressive activities, including the production of anti-inflammatory cytokines and the induction of Treg cells. However, Tim-3+ NK cells from patients with RM were less capable of inducing forkhead box P3 (Foxp3) ${ }^{+} \mathrm{T}$ cell generation in early pregnancy than cells from normal pregnant women. To the best of our knowledge, only a few research reports have explained the role of Tim-3 in the progression of ATD. However, there were no functional polymorphisms in the Tim-3 gene among the patients with HT and normal subjects in one small sample study [85]. Nonetheless, the expression of Tim-3 at the maternal-fetal interface in women with $\mathrm{HT}$, especially women with HT-related miscarriage, is worthy of further exploration because the inhibitory effect of Tim-3 has a profound impact on ADs and systemic immunity. Thus, Tim- $3^{+}$cells may not only become a biological marker for predicting the occurrence of miscarriage during early pregnancy but also be a potential target in immunotherapy for HT-related miscarriage. 


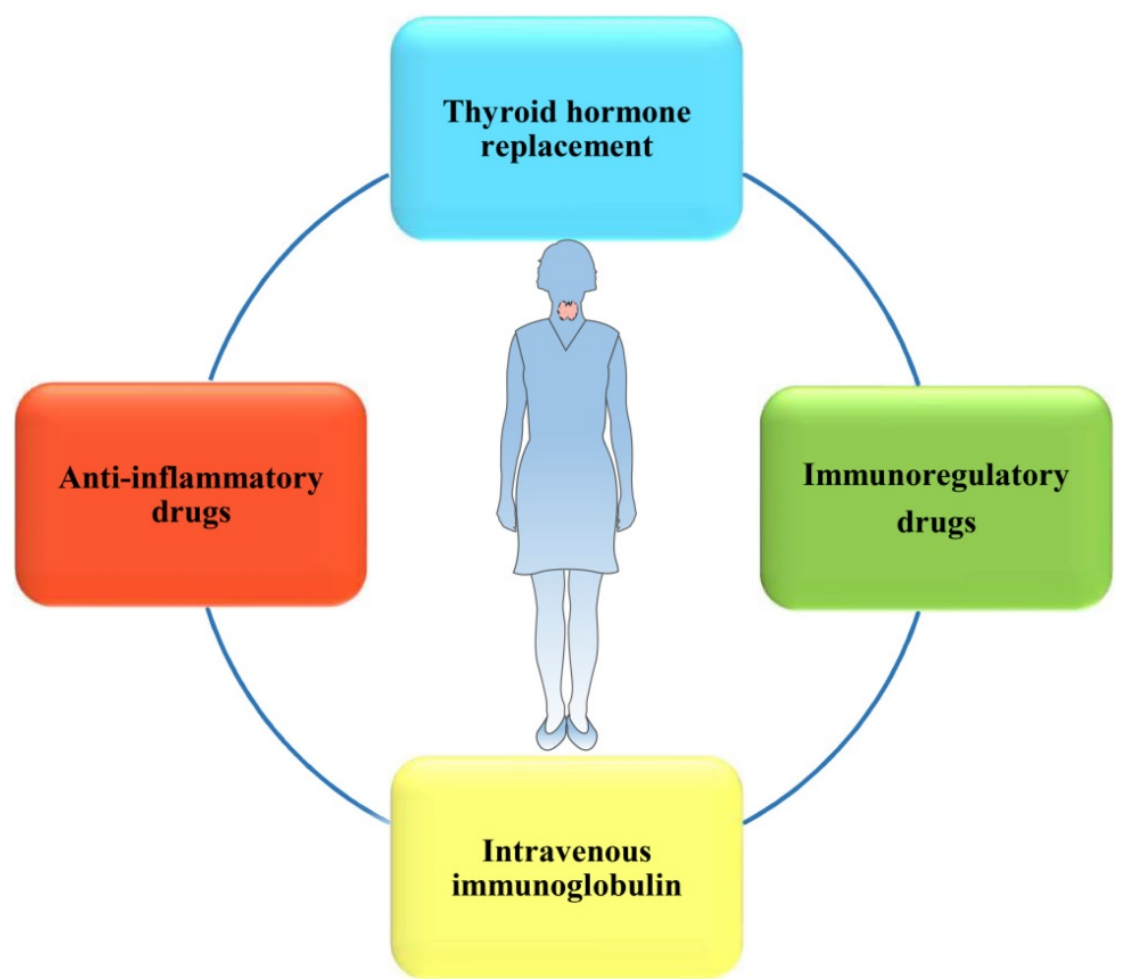

Figure 4. There are multiple treatments for women with HT to lower the risk of miscarriage and even RM, and the efficacies of them remain to be determined.

\section{FoxP3}

Generally, Treg cells are involved in maintaining immune homeostasis and self-tolerance by inhibiting the pro-inflammatory activities of $\mathrm{CD}^{+}$and $\mathrm{CD} 8^{+}$ effector T cells, NK cells, and antigen-presenting cells. More importantly, FoxP3, which is known as a critical transcription gene for Treg cell function, is regarded as an additional marker of the regulation of maternal immune tolerance [86]. However, the expression and polymorphisms of FoxP3 in patients with HT are lower and higher, respectively, than those observed in controls, which are often accompanied by decreased proportions of $\mathrm{CD}^{+}{ }^{+} \mathrm{CD} 25^{+} \mathrm{FoxP} 3^{+}$cells $[33,48,87,88]$. Therefore, the low expression level of Treg cells in women with HT may cause insufficient immunosuppression during pregnancy, which could impair the maternal tolerance to the semiallogeneic fetus and fetal development [89].

Indeed, multiple immune pathways are significantly correlated with HT and can further influence the process of pregnancy (Table 1), although the mechanisms by which circulating TPOAb or HT mediates systemic immune disorders are still unclear. In addition, with the development of cellular and molecular immunology, a range of immunotherapies aiming to decrease the miscarriage rate, including TNF- $\alpha$ inhibitors [90], intravenous immunoglobulin (IVIG) [59, 75], and other pathway inhibitors, have been introduced to clinical trials
[91-93]. However, we need to seriously consider the complications that such treatments may cause in pregnant women. Particularly in women with HT coexisting thyroid carcinoma (TC), suppressing the immune system may promote the central lymph node metastasis (CLNM) of tumors. Furthermore, highquality studies are needed to reveal the immunemediated mechanisms because understanding the immune-pathogenic mechanism underlying HTrelated miscarriage is pivotal for the development of novel immunotherapies.

\section{Treatments for HT-related miscarriage}

Currently, multiple treatments for HT-related miscarriage have been widely introduced to clinical trials or practices (Figure 4). Indeed, L-T4 supplementation, which is recommended by the American Thyroid Association (ATA) [32], is still the main treatment used to decrease the incidence of overt hypothyroidism during pregnancy among euthyroid women. Immunoregulatory drugs, such as selenium [94, 95] and vitamin D3 [96], have been discovered to efficiently alleviate HT progression and regulate the immune system, which may benefit pregnancy outcomes. However, the efficacies of these drug therapies are still controversial in different studies. In addition, to rebalance the immune system, IVIG may become a novel, potentially more effective therapeutic strategy used to maintain pregnancy in some women with HT. 


\section{Levothyroxine}

Currently, L-T4 remains the gold standard in the treatment of patients with hypothyroidism [97] and ranks as one of the most widely used drugs worldwide. Since the last century, a certain amount of evidence [23, 98] has demonstrated that adequate L-T4 supplementation $(25-50 \mu \mathrm{g} / \mathrm{d}$ as a typical starting dose) before pregnancy can decrease the risk of HT-related miscarriage and premature birth. L-T4 can not only maintain normal thyroid hormone levels but also inhibit the TSH level (below $2.5 \mathrm{mU} / \mathrm{L}$ ) [32]. However, with the exploration of autoimmune thyroiditis, many studies $[10,22,24,25]$ reached the contrary conclusion that regular L-T4 substitution could not decrease the risk of miscarriage in TPOAb-positive women (Figure 1B). Even in a recent report [99], a debate existed regarding whether a TPOAb-positive woman with a history of miscarriage needs low-dose L-T4 treatment to increase her chances of conceiving. Notably, one randomized controlled trial (RCT), performed by Dhillon-Smith et al. [22] concluded that there was no significant difference in the live birth rate between the group of TPOAb-positive euthyroid women who received L-T4 tablets $(50 \mu \mathrm{g} / \mathrm{d})$ for six months and the group of TPOAb-positive euthyroid women who were treated with placebo alone. The authors further indicated that pregnant women with HT cannot benefit from L-T4 supplementation decreasing the risk of adverse pregnancy outcomes. Notably, as these authors discussed, the main limitation of this trial was the fixed-dose of the L-T4 tablet supplementation instead of using a dosage based on the body mass index (BMI), which may be insufficient for women with a high BMI and, thus, could lead to negative results. Therefore, it is reasonable to consider adjusting the dose of L-T4 based on the serum TSH and thyroxine (T4) concentrations measured at each follow-up visit. Most recently, two meta-analyses performed by the group of Rao et al. [23, 98] confirmed that L-T4 supplementation treatment reduced the risk of miscarriage and preterm birth in women with HT with naturally conceived pregnancies. However, in women who underwent in vitro fertilization (IVF) or intracytoplasmic sperm injection (ICSI), the efficacies of L-T4 supplementation in preventing miscarriage or preterm birth were insufficient. Therefore, RCTs with larger sample sizes and different races and regions are needed to strengthen the evidence regarding the positive effects of L-T4 in decreasing the miscarriage rate among thyroid autoantibody-positive women.

Furthermore, L-T4 is a critical-dose drug because slight changes in the blood concentration may result in treatment failure and iatrogenic thyrotoxicosis. Therefore, for easier compliance and management, novel thyroxine formulations, including liquid preparations and softgel, have been invented in recent years [100]. Compared with traditional L-T4 preparations (tablets), these new types of L-T4 preparations at the same dose perform better in suppressing the serum TSH values and obtaining normal thyroid hormone levels, especially in pregnant women [101], unselected patients without evident malabsorption [102,103] and even euthyroid patients [104]. Choosing a more suitable L-T4 preparation for euthyroid women can not only reduce the impact of the drug absorption rate on the resulting efficacy in decreasing the miscarriage rate but also benefit precision medicine with individualization of the L-T4 dose.

\section{Selenium}

Selenium is an essential trace mineral, and the thyroid has a higher concentration of selenium than most other organs, reflecting the importance of selenium for thyroid metabolism [105]. Selenium has been identified as a component of multiple enzymes that have numerous functions ranging from antioxidant and anti-inflammatory roles to the production of active thyroid hormone [106]. Selenium deficiency can not only impair thyroid hormone synthesis and metabolism but also lead to an imbalance in the immune system [107]. Many surveys have demonstrated that women with HT often have selenium deficiency, which may reflect the potential immune disorders in these patients [94, 108]. Meanwhile, numerous studies have shown that a significant decrease in serum anti-thyroid antibodies was present in patients who received Se supplementation. For instance, as determined in a systematic review and meta-analysis, Se supplementation $(60-200 \mu \mathrm{g} / \mathrm{d}$ in different trials) can significantly decrease the anti-thyroid antibody level, especially the serum TPOAb level, in the L-T4-treated population [109]. This result is consistent with findings showing a decreasing autoantibody titer in another double-blind RCT in Italy (45 cases), [110]. The latter study further concluded that Se supplementation was safe during pregnancy and after delivery at a dosage of $83 \mathrm{mcg} / \mathrm{d}$. [110]. Interestingly, some research did not find that isolated Se supplementation can prevent the progression of HT [111-113], while combined treatment with L-T4 supplementation was observed to improve the therapeutic effects in delaying the deterioration of chronic inflammation in HT compared with L-T4 monotherapy [114]. Thus, the efficacies of Se supplementation in ATDs and even pregnancy outcomes remain controversial. The main reasons for this divergence could be the different doses and 
preparations of Se $(200 \mu \mathrm{g} / \mathrm{d}$ vs. $60 \mu \mathrm{g} / \mathrm{d})$ used in these trials and whether the individual treatments were combined with L-T4 supplementation. Selenium compounds, such as selenomethionine, sodium selenite, and selenium yeast, which are prescribed to patients, vary among studies [109]. Furthermore, there are still many other confounding factors in the inclusion criteria, such as other nutritional deficiencies, geographical location, dietary habits, initial thyroid function, and other concurrent NEADs. Some previous studies have found that women suffering from miscarriage or RM had lower concentrations of Se than healthy controls $[115,116]$. Even in two recent review reports, both studies further highlighted that Se deficiency is significantly associated with disorders related to human reproduction and pregnancy $[117,118]$. However, sufficient evidence regarding the efficacy of Se supplementation in decreasing antithyroid antibodies and preventing miscarriage in euthyroid women is lacking $[112,119,120]$. Therefore, more studies are needed to provide better clinical evidence proving the ability of Se to reduce thyroid inflammation. Additionally, evidence suggesting that thyroid antibodies can directly damage the placenta is limited. Moreover, a high concentration of selenium in PB could be toxic to pregnant women and their fetuses $[121,122]$. Thus, following the ethical principle of "First do no harm" and the recommendation in the 2017 ATA guideline [32], currently, high-level evidence supporting the routine use of Se supplementation in TPOAb-positive women during pregnancy to decrease the risk of miscarriage is lacking.

\section{Vitamin D3}

Vitamin $D$ has been found to play an increasingly crucial regulatory role in bone metabolism, the mucosal barrier, and the immune system in the past few decades. More recently, numerous studies have highlighted that an insufficient level of 25-hydroxyvitamin D [25(OH)D] is significantly associated with HT [123-125].

Thus, 25(OH)D supplementation seems to be a potentially effective method for alleviating HT progression and moderating the immune system to achieve a better pregnancy. For instance, one RCT found that women with HT treated with cholecalciferol (vitamin D3) supplementation for three months had a significant decrease in the Th17/Th1 ratio $(p<0.046)$ and enhanced expression of IL-10, even though the serum vitamin D level in the two groups did not significantly differ after the treatment [35]. In addition, the efficacy of vitamin D in decreasing the TPOAb level is still debatable. Some studies [126, 127] found that vitamin D3 can significantly reduce the TPOAb levels, but one study [128] reached the following different conclusion: there was no significant reduction in the TPOAb levels in the vitamin $\mathrm{D}$ group compared with the placebo group $(p=0.08)$. Indeed, many beneficial effects of vitamin D3 supplementations in patients with HT have been observed in different clinical trials. However, the dose-limiting toxicities of vitamin D3 are also nonnegligible risk factors during treatment. Further studies are needed to obtain better clinical evidence to support clinical decision making, especially for women with HT, and determine whether they can benefit from these immunomodulatory drugs, including Se and vitamin D3, before and during gestation.

\section{Intravenous immunoglobulin}

IVIG has been regarded as a lifesaving treatment for patients with primary immunodeficiency or severe infection in the last centuries [129, 130]. More importantly, during the past few decades, accumulating studies have found that IVIG could regulate the immune system, such as NK cells, Th1 cells, and Th2 cells, which might be helpful for patients with ADs [131-133]. Many studies have discovered that women with RM presented an abnormal activation of the immune system [134-136]; IVIG is currently introduced as a novel treatment for women with RM. Expectedly, the results are encouraging [59, 137-141] and show that IVIG can significantly increase reproductive success in women with a history of RM. For instance, Ahmadi et al. [59] found that IVIG can dramatically regulate the Th1/Th2 ratio by decreasing Th1 $\left(\mathrm{CD}^{+}\right.$IFN- $\left.\gamma^{+}\right)$cells and increasing Th2 $\left(\mathrm{CD}^{+} \mathrm{IL}-4^{+}\right)$cells $(p<0.0001)$. Additionally, the birth rate in the IVIG group was significantly higher than that in the control group $(87.5 \%$ vs. $41.6 \%, p<0.0001)$. Furthermore, in another study [75], the authors demonstrated that IVIG could decrease the number of NK cells and the activating receptors KIR2DS1, KIR2DS4, and NKG2D in women with RM. As some research concluded, low-dose $(0.2$ $\mathrm{g} / \mathrm{kg}$ ) IVIG therapy can significantly increase the live birth rate in women with HT by rebalancing the functions of the immune system $[142,143]$.

Nonetheless, in recent years, some scholars [144, 145] have held different views regarding this immunotherapy in women with RM. On the one hand, in some earlier research [146, 147], compared with the control (placebo) group, IVIG had no significant beneficial effect on decreasing the miscarriage rate in women with RM. On the other hand, in contrast to CD56 dim NK cells, dNK [148-150] cells perform poorly in exhibiting cytotoxicity or 
secreting IFN- $\gamma$. However, these cells play an essential role in regulating maternal tolerance to the semiallogeneic embryo and the invasion of trophoblast cells, which is essential for forming the placenta. Numerous immunotherapies may harm this process without any benefit. In addition, IVIG could affect the maternal immune system without guaranteed beneficial results and is often accompanied by mild adverse events.

In recent years, different studies have reported that IVIG has positive impacts on increasing the live birth rate in women with RM [59, 75, 142]; however, the high cost per infusion and possible side effects, such as fever and even anaphylaxis, should be carefully considered during the treatment decisionmaking process. Due to the lack of high-level clinical evidence, IVIG treatment is still not recommended for euthyroid women with a history of recurrent pregnancy loss. Further RCTs are needed to determine whether IVIG treatment has long-term effectiveness in women who suffer from HT-related miscarriage and evaluate the comparative efficacy with drug therapies at different levels.

\section{Conclusion}

Although significant progress has been made in our understanding of the contributions of immune dysfunctions triggers to HT related miscarriage, its pathogenesis is still not fully comprehended. In recent years, it confirmed the abnormal expression levels of multiple immune cells and cytokines in HT patients, especially the proinflammatory polarization of naïve T cells and NK cells. Meanwhile, the role of Breg cells in immune-mediated diseases has been also recognized, but the significance of the participation of Breg cells in the progression of HT is rather insufficient. The specific changes of these immune cells and cytokines can not only positively contribute to a better understanding of the role of immune dysfunctions in HT women with adverse pregnancy outcomes, but also provide further insights into the novel treatment for HT related miscarriage. Furthermore, even though multiple immunotherapies in decreasing the risk of HT related miscarriage have been introduced to the clinical trials and practice, the efficacies and safety of these drugs are still needed to have further evaluation. Nevertheless, the rapidly advancing in this field is becoming the most potential treatment component of HT related miscarriage.

\section{Abbreviations}

HT: Hashimoto's thyroiditis; ATD: autoimmune thyroid disease; RM: recurrent miscarriage; Se: selenium; IVIG: intravenous immunoglobulin; CLT: chronic lymphocytic thyroiditis; ADs: autoimmune diseases; NEADs: nonendocrine autoimmune disorders; E2: estradiol; $\mathrm{SH}$ : subclinical hypothyroidism; Treg: $\mathrm{T}$ regulatory cells; Breg: B regulatory cells; Th2: $\mathrm{T}$ helper type 2; L-T4: L-thyroxine; TgAb: thyroid globulin antibody; TPOAb: thyroid peroxidase antibody; TSH: thyroidstimulating hormone; PB: peripheral blood; IL: interleukin; TGF- $\beta$ : transforming growth factor-beta; Th1: T-helper type1; Th17: T-helper type17; INF-ү: interferon-gamma; TNF-a: tumor necrosis factoralpha; EVTs: extravillous trophoblast cells; ADCC: antibody-dependent cell-mediated cytotoxicity; dNK: decidual NK; PD-1: programmed cell death-1; Tim-3: T-cell immunoglobulin mucin-3; PD-L1: programmed cell death-Ligand 1; DTC: differentiated thyroid carcinoma; $\mathrm{dCD}^{+} \mathrm{T}$ : decidual $\mathrm{CD}^{+} \mathrm{T}$; FoxP3: forkhead box P3; TC: thyroid carcinoma; CLNM: central lymph node metastasis; ATA: the American Thyroid Association; RCTs: randomized controlled trials; BMI: body mass index; T4: thyroxine; IVF: vitro fertilization; ICSI: intracytoplasmic sperm injection; 25(OH)D: 25-hydroxyvitamin D; Vitamin D3: cholecalciferol; PTC: papillary thyroid carcinoma; PT: partial thyroidectomy; U/D/I: up-regulated/downregulated/impaired; $\mathrm{Tfh}$ : follicular helper $\mathrm{T}$ cell; MHC: major histocompatibility complex.

\section{Acknowledgments}

This review did not receive any specific grant from funding agencies in the public, commercial, or not-for-profit sectors.

\section{Competing Interests}

The authors have declared that no competing interest exists.

\section{References}

1. Ragusa F, Fallahi P, Elia G, Gonnella D, Paparo SR, Giusti C, et al. Hashimotos' thyroiditis: Epidemiology, pathogenesis, clinic and therapy. Best Pract Res Clin Endocrinol Metab. 2019; 101367.

2. Caturegli P, De Remigis A, Rose NR. Hashimoto thyroiditis: clinical and diagnostic criteria. Autoimmunity reviews. 2014; 13: 391-7.

3. McLeod DSA, Cooper DS. The incidence and prevalence of thyroid autoimmunity. Endocrine. 2012; 42: 252-65.

4. Antonelli A, Ferrari SM, Corrado A, Di Domenicantonio A, Fallahi P. Autoimmune thyroid disorders. Autoimmunity reviews. 2015; 14: 174-80.

5. San Lazaro Campillo I, Meaney S, O'Donoghue K, Corcoran P. Miscarriage hospitalisations: a national population-based study of incidence and outcomes, 2005-2016. Reprod Health. 2019; 16: 51.

6. Linnakaari R, Helle N, Mentula M, Bloigu A, Gissler M, Heikinheimo O, et al. Trends in the incidence, rate and treatment of miscarriage-nationwide register-study in Finland, 1998-2016. Human reproduction (Oxford, England). 2019; 34: 2120-8.

7. Daniely M, Aviram-Goldring A, Barkai G, Goldman B. Detection of chromosomal aberration in fetuses arising from recurrent spontaneous abortion by comparative genomic hybridization. Hum Reprod. 1998; 13: 805-9.

8. Jacob L, Gerhard C, Kostev K, Kalder M. Association between induced abortion, spontaneous abortion, and infertility respectively and the risk of psychiatric disorders in 57,770 women followed in gynecological practices in Germany. J Affect Disord. 2019; 251: 107-13.

9. Xie J, Jiang L, Sadhukhan A, Yang S, Yao Q, Zhou P, et al. Effect of antithyroid antibodies on women with recurrent miscarriage: A meta-analysis. Am J Reprod Immunol. 2020; e13238.

10. Wang H, Gao H, Chi H, Zeng L, Xiao W, Wang Y, et al. Effect of Levothyroxine on Miscarriage Among Women With Normal Thyroid Function and Thyroid 
Autoimmunity Undergoing In vitro Fertilization and Embryo Transfer: A Randomized Clinical Trial. JAMA. 2017; 318: 2190-8.

11. Liu H, Shan Z, Li C, Mao J, Xie X, Wang W, et al. Maternal subclinical hypothyroidism, thyroid autoimmunity, and the risk of miscarriage: a prospective cohort study. Thyroid. 2014; 24: 1642-9.

12. Lata K, Dutta P, Sridhar S, Rohilla M, Srinivasan A, Prashad GR, et al. Thyroid autoimmunity and obstetric outcomes in women with recurrent miscarriage: a case-control study. Endocr Connect. 2013; 2: 118-24.

13. Stagnaro-Green A, Glinoer D. Thyroid autoimmunity and the risk of miscarriage. Best Pract Res Clin Endocrinol Metab. 2004; 18: 167-81.

14. Magnusson L, Barcenilla H, Pihl M, Bensing S, Espes D, Carlsson PO, et al. Mass Cytometry Studies of Patients With Autoimmune Endocrine Diseases Reveal Distinct Disease-Specific Alterations in Immune Cell Subsets. Front Immunol. 2020; 11: 288 .

15. Liu Y, You R, Yu N, Gong Y, Qu C, Zhang Y, et al. Increased proportions of Tc17 cells and NK cells may be risk factors for disease progression in Hashimoto's thyroiditis. Int Immunopharmacol. 2016; 40: 332-8.

16. Kim NY, Cho HJ, Kim HY, Yang KM, Ahn HK, Thornton S, et al. Thyroid autoimmunity and its association with cellular and humoral immunity in women with reproductive failures. Am J Reprod Immunol. 2011; 65: 78-87.

17. Turhan Iyidir O, Konca Degertekin C, Sonmez C, Atak Yucel A, Erdem M, Akturk M, et al. The effect of thyroid autoimmunity on T-cell responses in early pregnancy. Journal of reproductive immunology. 2015; 110: 61-6.

18. Konova $\mathrm{E}$. The role of NK cells in the autoimmune thyroid disease-associated pregnancy loss. Clin Rev Allergy Immunol. 2010; 39: 176-84.

19. Salvany-Celades M, van der Zwan A, Benner M, Setrajcic-Dragos V, Bougleux Gomes HA, Iyer V, et al. Three Types of Functional Regulatory T Cells Control T Cell Responses at the Human Maternal-Fetal Interface. Cell Rep. 2019; 27: 2537-47.e5.

20. Robertson SA, Care AS, Moldenhauer LM. Regulatory T cells in embryo implantation and the immune response to pregnancy. J Clin Invest. 2018; 128: 4224-35.

21. Wang S, Zhu X, Xu Y, Zhang D, Li Y, Tao Y, et al. Programmed cell death-1 (PD-1) and T-cell immunoglobulin mucin-3 (Tim-3) regulate CD4+ T cells to induce Type 2 helper T cell (Th2) bias at the maternal-fetal interface. Hum Reprod. 2016; 31: 700-11.

22. Dhillon-Smith RK, Middleton LJ, Sunner KK, Cheed V, Baker K, Farrell-Carver $\mathrm{S}$, et al. Levothyroxine in Women with Thyroid Peroxidase Antibodies before Conception. N Engl J Med. 2019; 380: 1316-25.

23. Rao M, Zeng Z, Zhou F, Wang H, Liu J, Wang R, et al. Effect of levothyroxine supplementation on pregnancy loss and preterm birth in women with subclinical hypothyroidism and thyroid autoimmunity: a systematic review and meta-analysis. Hum Reprod Update. 2019; 25: 344-61.

24. Nazarpour S, Ramezani Tehrani F, Simbar M, Tohidi M, Alavi Majd H, Azizi F. Effects of levothyroxine treatment on pregnancy outcomes in pregnant women with autoimmune thyroid disease. Eur J Endocrinol. 2017; 176: 253-65.

25. Negro R, Schwartz A, Stagnaro-Green A. Impact of Levothyroxine in Miscarriage and Preterm Delivery Rates in First Trimester Thyroid Antibody-Positive Women With TSH Less Than 2.5 mIU/L. J Clin Endocrinol Metab. 2016; 101: 3685-90.

26. Li Y, Teng D, Ba J, Chen B, Du J, He L, et al. Efficacy and Safety of Long-Term Universal Salt Iodization on Thyroid Disorders: Epidemiological Evidence from 31 Provinces of Mainland China. Thyroid. 2020; 30: 568-79.

27. Biondi B, Cappola AR, Cooper DS. Subclinical Hypothyroidism: A Review. JAMA. 2019; 322: 153-60.

28. Korevaar TIM, Derakhshan A, Taylor PN, Meima M, Chen L, Bliddal S, et al. Association of Thyroid Function Test Abnormalities and Thyroid Autoimmunity With Preterm Birth: A Systematic Review and Meta-analysis. JAMA. 2019; 322: 632-41.

29. Bachimanchi B, Vaikkakara S, Sachan A, Praveen Kumar G, Venkatanarasu A, Sai Krishna Chaitanya P, et al. Effect of Adequate Thyroid Hormone Replacement on the Hypothalamo-Pituitary-Gonadal Axis in Premenopausal Women with Primary Hypothyroidism. Eur Thyroid J. 2019; 8: 152-8.

30. Krassas GE, Poppe K, Glinoer D. Thyroid function and human reproductive health. Endocr Rev. 2010; 31: 702-55.

31. De Groot L, Abalovich M, Alexander EK, Amino N, Barbour L, Cobin RH, et al. Management of thyroid dysfunction during pregnancy and postpartum: an Endocrine Society clinical practice guideline. J Clin Endocrinol Metab. 2012; 97: 2543-65.

32. Alexander EK, Pearce EN, Brent GA, Brown RS, Chen H, Dosiou C, et al. 2017 Guidelines of the American Thyroid Association for the Diagnosis and Management of Thyroid Disease During Pregnancy and the Postpartum. Thyroid : official journal of the American Thyroid Association. 2017; 27: 315-89.

33. Yang $X$, Lun $Y$, Jiang $H$, Liu X, Duan Z, Xin S, et al. SIRT1-Regulated Abnormal Acetylation of FOXP3 Induces Regulatory T-Cell Function Defect in Hashimoto's Thyroiditis. Thyroid. 2018; 28: 246-56

34. Zhao J, Chen Y, Zhao Q, Shi J, Yang W, Zhu Z, et al. Increased circulating Tfh17 and PD-1(+)Tfh cells are associated with autoantibodies in Hashimoto's thyroiditis. Autoimmunity. 2018; 51: 352-9.

35. Nodehi M, Ajami A, Izad M, Asgarian Omran H, Chahardoli R, Amouzegar A, et al. Effects of vitamin D supplements on frequency of CD4(+) T-cell subsets in women with Hashimoto's thyroiditis: a double-blind placebo-controlled study. Eur J Clin Nutr. 2019; 73: 1236-43.
36. Jurkovic D, Overton $C$, Bender-Atik $R$. Diagnosis and management of first trimester miscarriage. BMJ (Clinical research ed). 2013; 346: f3676.

37. Hertz-Picciotto I, Samuels SJ. Incidence of early loss of pregnancy. The New England journal of medicine. 1988; 319: 1483-4

38. Pratt D, Novotny M, Kaberlein G, Dudkiewicz A, Gleicher N. Antithyroid antibodies and the association with non-organ-specific antibodies in recurrent pregnancy loss. Am J Obstet Gynecol. 1993; 168: 837-41.

39. Beneventi F, Locatelli E, Caporali R, Alpini C, Lovati E, Ramoni V, et al. Connective tissue diseases and autoimmune thyroid disorders in the first trimester of pregnancy. J Reprod Immunol. 2016; 114: 32-7.

40. Cellini M, Santaguida MG, Stramazzo I, Capriello S, Brusca N, Antonelli A, et al. Recurrent Pregnancy Loss in Women with Hashimoto's Thyroiditis with Concurrent Non-Endocrine Autoimmune Disorders. Thyroid : official journal of the American Thyroid Association. 2020; 30: 457-62.

41. De Leo S, Pearce EN. Autoimmune thyroid disease during pregnancy. Lancet Diabetes Endocrinol. 2018; 6: 575-86.

42. Chen $\mathrm{L}, \mathrm{Hu}$ R. Thyroid autoimmunity and miscarriage: a meta-analysis. Clin Endocrinol (Oxf). 2011; 74: 513-9.

43. Stagnaro-Green A, Roman SH, Cobin RH, el-Harazy E, Alvarez-Marfany M, Davies TF. Detection of at-risk pregnancy by means of highly sensitive assays for thyroid autoantibodies. JAMA. 1990; 264: 1422-5.

44. Rodríguez-Muñoz A, Vitales-Noyola M, Ramos-Levi A, Serrano-Somavilla A, González-Amaro R, Marazuela M. Levels of regulatory $\mathrm{T}$ cells CD69(+)NKG2D(+)IL-10(+) are increased in patients with autoimmune thyroid disorders. Endocrine. 2016; 51: 478-89.

45. Bagis T, Gokcel A, Saygili ES. Autoimmune thyroid disease in pregnancy and the postpartum period: relationship to spontaneous abortion. Thyroid : official journal of the American Thyroid Association. 2001; 11: 1049-53.

46. Bliddal S, Feldt-Rasmussen U, Rasmussen AK, Kolte AM, Hilsted LM, Christiansen OB, et al. Thyroid Peroxidase Antibodies and Prospective Live Birth Rate: A Cohort Study of Women with Recurrent Pregnancy Loss. Thyroid. 2019; 29: 1465-74.

47. Pratt DE, Kaberlein G, Dudkiewicz A, Karande V, Gleicher N. The association of antithyroid antibodies in euthyroid nonpregnant women with recurrent first trimester abortions in the next pregnancy. Fertility and Sterility. 1993; 60: 1001-5.

48. Hu Y, Zhang L, Chen H, Liu X, Zheng X, Shi H, et al. Analysis of Regulatory T Cell Subsets and Their Expression of Helios and PD-1 in Patients with Hashimoto Thyroiditis. Int J Endocrinol. 2019; 2019: 5368473.

49. Ali S, Majid S, Niamat Ali M, Taing S. Evaluation of T cell cytokines and their role in recurrent miscarriage. Int Immunopharmacol. 2020; 82: 106347.

50. Figueroa-Vega $\mathrm{N}$, Alfonso-Pérez $\mathrm{M}$, Benedicto $\mathrm{I}$, Sánchez-Madrid $\mathrm{F}$, González-Amaro R, Marazuela Mn. Increased Circulating Pro-Inflammatory Cytokines and Th17 Lymphocytes in Hashimoto's Thyroiditis. The Journal of Clinical Endocrinology \& Metabolism. 2010; 95. 953-62.

51. Logiodice F, Lombardelli L, Kullolli O, Haller H, Maggi E, Rukavina D, et al. Decidual Interleukin-22-Producing CD4+ T Cells (Th17/Th0/IL-22+ and Th17/Th2/IL-22+, Th2/IL-22+, Th0/IL-22+), Which Also Produce IL-4, Are Involved in the Success of Pregnancy. Int J Mol Sci. 2019; 20.

52. Salomon C, Yee SW, Mitchell MD, Rice GE. The possible role of extravillous trophoblast-derived exosomes on the uterine spiral arterial remodeling under both normal and pathological conditions. Biomed Res Int. 2014; 2014: 693157.

53. Ashkar AA, Di Santo JP, Croy BA. Interferon gamma contributes to initiation of uterine vascular modification, decidual integrity, and uterine natural killer cell maturation during normal murine pregnancy. J Exp Med. 2000; 192: 259-70.

54. Azizieh FY, Raghupathy R. IL-10 and pregnancy complications. Clin Exp Obstet Gynecol. 2017; 44: 252-8.

55. Marzi M, Vigano A, Trabattoni D, Villa ML, Salvaggio A, Clerici E, et al. Characterization of type 1 and type 2 cytokine production profile in physiologic and pathologic human pregnancy. Clin Exp Immunol. 1996; 106: $127-33$.

56. Chatterjee P, Chiasson VL, Bounds KR, Mitchell BM. Regulation of the Anti-Inflammatory Cytokines Interleukin-4 and Interleukin-10 during Pregnancy. Front Immunol. 2014; 5: 253.

57. Ghaebi M, Nouri M, Ghasemzadeh A, Farzadi L, Jadidi-Niaragh F, Ahmadi M, et al. Immune regulatory network in successful pregnancy and reproductive failures. Biomed Pharmacother. 2017; 88: 61-73.

58. Nanba $\mathrm{T}$, Watanabe $\mathrm{M}$, Inoue $\mathrm{N}$, Iwatani $\mathrm{Y}$. Increases of the Th1/Th2 cell ratio in severe Hashimoto's disease and in the proportion of Th17 cells in intractable Graves' disease. Thyroid : official journal of the American Thyroid Association. 2009; 19: 495-501.

59. Ahmadi M, Abdolmohammadi-Vahid S, Ghaebi M, Aghebati-Maleki L, Afkham A, Danaii S, et al. Effect of Intravenous immunoglobulin on Th1 and Th2 lymphocytes and improvement of preonancy outcome in recurrent pregnancy loss (RPL). Biomed Pharmacother. 2017; 92: 1095-102.

60. Zake T, Skuja S, Kalere I, Konrade I, Groma V. Upregulated tissue expression of T helper (Th) 17 pathogenic interleukin (IL)-23 and IL-1 $\beta$ in Hashimoto's thyroiditis but not in Graves' disease. Endocr J. 2019; 66: 423-30.

61. Vitales-Noyola M, Ramos-Levi AM, Martínez-Hernández R, Serrano-Somavilla A, Sampedro-Nuñez M, González-Amaro R, et al. Pathogenic Th17 and Th22 cells are increased in patients with autoimmune thyroid disorders. Endocrine. 2017; 57: 409-17.

62. Qin Q, Liu P, Liu L, Wang R, Yan N, Yang J, et al. The increased but non-predominant expression of Th17- and Th1-specific cytokines in 
Hashimoto's thyroiditis but not in Graves' disease. Braz J Med Biol Res. 2012; 45: $1202-8$.

63. Santaguida MG, Nardo S, Del Duca SC, Lococo E, Virili C, Gargano L, et al. Increased interleukin-4-positive lymphocytes in patients with Hashimoto's thyroiditis and concurrent non-endocrine autoimmune disorders. Clin Exp Immunol. 2011; 165: 148-54.

64. Lipsky PE. Systemic lupus erythematosus: an autoimmune disease of B cell hyperactivity. Nat Immunol. 2001; 2: 764-6.

65. Santaguida MG, Gatto I, Mangino G, Virili C, Stramazzo I, Fallahi P, et al. BREG cells in Hashimoto's thyroiditis isolated or associated to further organ-specific autoimmune diseases. Clin Immunol. 2017; 184: 42-7.

66. Yu S, Qi Y, Wang H, Jiang J, Sun L, Zhou Q. Dysfunction of CD24+CD38+ B cells in patients with Hashimoto's thyroiditis is associated with a lack of interleukin 10. Int J Biochem Cell Biol. 2017; 90: 114-20.

67. Mauri C, Bosma A. Immune regulatory function of B cells. Annu Rev Immunol. 2012; 30: 221-41.

68. Flores-Borja F, Bosma A, Ng D, Reddy V, Ehrenstein MR, Isenberg DA, et al. CD19+CD24hiCD38hi B cells maintain regulatory T cells while limiting TH1 and TH17 differentiation. Sci Transl Med. 2013; 5: 173ra23.

69. Kalampokis I, Yoshizaki A, Tedder TF. IL-10-producing regulatory B cells (B10 cells) in autoimmune disease. Arthritis Res Ther. 2013; 15 Suppl 1: S1.

70. Blair PA, Noreña LY, Flores-Borja F, Rawlings DJ, Isenberg DA, Ehrenstein MR, et al. CD19(+)CD24(hi)CD38(hi) B cells exhibit regulatory capacity in healthy individuals but are functionally impaired in systemic Lupus Erythematosus patients. Immunity. 2010; 32: 129-40.

71. Esteve-Solé A, Teixidó I, Deyà-Martínez A, Yagüe J, Plaza-Martín AM, Juan M, et al. Characterization of the Highly Prevalent Regulatory CD24(hi)CD38(hi) B-Cell Population in Human Cord Blood. Front Immunol. 2017; 8: 201.

72. Hammer Q, Romagnani C. About Training and Memory: NK-Cell Adaptation to Viral Infections. Adv Immunol. 2017; 133: 171-207.

73. Zhang C, Tian Z. NK cell subsets in autoimmune diseases. J Autoimmun. 2017; 83: 22-30.

74. Tao Y, Li YH, Piao HL, Zhou WJ, Zhang D, Fu Q, et al. CD56(bright)CD25+ NK cells are preferentially recruited to the maternal/fetal interface in early human pregnancy. Cell Mol Immunol. 2015; 12: 77-86.

75. Ahmadi M, Ghaebi M, Abdolmohammadi-Vahid S, Abbaspour-Aghdam S, Hamdi K, Abdollahi-Fard S, et al. NK cell frequency and cytotoxicity in correlation to pregnancy outcome and response to IVIG therapy among women with recurrent pregnancy loss. J Cell Physiol. 2019; 234: 9428-37.

76. Cimino-Mathews A, Thompson E, Taube JM, Ye X, Lu Y, Meeker A, et al. PD-L1 (B7-H1) expression and the immune tumor microenvironment in primary and metastatic breast carcinomas. Hum Pathol. 2016; 47: 52-63.

77. Takamori S, Takada K, Tagawa T, Toyokawa G, Hirai F, Yamashita N, et al. Differences in PD-L1 expression on tumor and immune cells between lung metastases and corresponding primary tumors. Surg Oncol. 2018; 27: 637-41.

78. Cha JH, Chan LC, Li CW, Hsu JL, Hung MC. Mechanisms Controlling PD-L1 Expression in Cancer. Mol Cell. 2019; 76: 359-70.

79. Álvarez-Sierra D, Marín-Sánchez A, Ruiz-Blázquez $P$, de Jesús Gil C, Iglesias-Felip C, González Ó, et al. Analysis of the PD-1/PD-L1 axis in human autoimmune thyroid disease: Insights into pathogenesis and clues to immunotherapy associated thyroid autoimmunity. J Autoimmun. 2019; 103: 102285.

80. Lubin D, Baraban E, Lisby A, Jalali-Farahani S, Zhang P, Livolsi V. Papillary Thyroid Carcinoma Emerging from Hashimoto Thyroiditis Demonstrates Increased PD-L1 Expression, Which Persists with Metastasis. Endocr Pathol. 2018; 29: 317-23.

81. Shi RL, Qu N, Luo TX, Xiang J, Liao T, Sun GH, et al. Programmed Death-Ligand 1 Expression in Papillary Thyroid Cancer and Its Correlation with Clinicopathologic Factors and Recurrence. Thyroid. 2017; 27: 537-45.

82. Wang S, Sun F, Li M, Qian J, Chen C, Wang M, et al. The appropriate frequency and function of decidual Tim-3(+)CTLA-4(+)CD8(+) T cells are important in maintaining normal pregnancy. Cell Death Dis. 2019; 10: 407.

83. Xu YY, Wang SC, Lin YK, Li DJ, Du MR. Tim-3 and PD-1 regulate CD8(+) T cell function to maintain early pregnancy in mice. J Reprod Dev. 2017; 63: 289-94.

84. Li Y, Zhang J, Zhang D, Hong X, Tao Y, Wang S, et al. Tim-3 signaling in peripheral NK cells promotes maternal-fetal immune tolerance and alleviates pregnancy loss. Sci Signal. 2017; 10.

85. Inoue N, Watanabe M, Nakaguchi A, Ueda D, Kawaguti H, Hidaka Y, et al. Functional polymorphisms affecting Th1 differentiation are associated with the severity of autoimmune thyroid diseases. Endocr J. 2017; 64: 695-703.

86. Scarpellini F, Klinger FG, Rossi G, Sbracia M. Immunohistochemical Study on the Expression of G-CSF, G-CSFR, VEGF, VEGFR-1, Foxp3 in First Trimester Trophoblast of Recurrent Pregnancy Loss in Pregnancies Treated with G-CSF and Controls. Int J Mol Sci. 2019; 21.

87. Chen Z, Wang Y, Ding X, Zhang M, He M, Zhao Y, et al. The proportion of peripheral blood Tregs among the CD4+ $\mathrm{T}$ cells of autoimmune thyroid disease patients: a meta-analysis. Endocr J. 2020; 67: 317-26.

88. Kristensen B, Hegedüs L, Madsen HO, Smith TJ, Nielsen CH. Altered balance between self-reactive $\mathrm{T}$ helper (Th)17 cells and Th10 cells and between full-length forkhead box protein 3 (FoxP3) and FoxP3 splice variants in Hashimoto's thyroiditis. Clin Exp Immunol. 2015; 180: 58-69.

89. Kwiatek M, Gęca T, Krzyżanowski A, Malec A, Kwaśniewska A. Peripheral Dendritic Cells and CD4+CD25+Foxp3+ Regulatory T Cells in the First
Trimester of Normal Pregnancy and in Women with Recurrent Miscarriage. PLoS One. 2015; 10: e0124747.

90. Winger EE, Reed JL. Treatment with tumor necrosis factor inhibitors and intravenous immunoglobulin improves live birth rates in women with recurrent spontaneous abortion. Am J Reprod Immunol. 2008; 60: 8-16.

91. Achilli C, Duran-Retamal M, Saab W, Serhal P, Seshadri S. The role of immunotherapy in in vitro fertilization and recurrent pregnancy loss: a systematic review and meta-analysis. Fertil Steril. 2018; 110: 1089-100.

92. Homer HA. Modern management of recurrent miscarriage. Aust N Z J Obstet Gynaecol. 2019; 59: 36-44

93. Hviid MM, Macklon N. Immune modulation treatments-where is the evidence? Fertil Steril. 2017; 107: 1284-93.

94. Duntas LH. The Role of Iodine and Selenium in Autoimmune Thyroiditis. Horm Metab Res. 2015; 47: 721-6.

95. Rayman MP. Multiple nutritional factors and thyroid disease, with particular reference to autoimmune thyroid disease. Proc Nutr Soc. 2019; 78: 34-44.

96. Altieri B, Muscogiuri G, Barrea L, Mathieu C, Vallone CV, Mascitelli L, et al. Does vitamin D play a role in autoimmune endocrine disorders? A proof of concept. Reviews in endocrine \& metabolic disorders. 2017; 18: 335-46.

97. Jonklaas J, Bianco AC, Bauer AJ, Burman KD, Cappola AR, Celi FS, et al. Guidelines for the treatment of hypothyroidism: prepared by the american thyroid association task force on thyroid hormone replacement. Thyroid : official journal of the American Thyroid Association. 2014; 24: 1670-751.

98. Rao M, Zeng Z, Zhao S, Tang L. Effect of levothyroxine supplementation on pregnancy outcomes in women with subclinical hypothyroidism and thyroid autoimmuneity undergoing in vitro fertilization/intracytoplasmic sperm injection: an updated meta-analysis of randomized controlled trials. Reprod Biol Endocrinol. 2018; 16: 92

99. Chen AX, Leung AM, Korevaar TIM. Thyroid Function and Conception. N Engl J Med. 2019; 381: 178-81.

100. Virili C, Trimboli P, Centanni M. Novel thyroxine formulations: a further step toward precision medicine. Endocrine. 2019; 66: 87-94.

101. Cappelli C, Negro R, Pirola I, Gandossi E, Agosti B, Castellano M. Levothyroxine liquid solution versus tablet form for replacement treatment in pregnant women. Gynecol Endocrinol. 2016; 32: 290-2.

102. Negro R, Valcavi R, Agrimi D, Toulis KA. Levothyroxine liquid solution versus tablet for replacement treatment in hypothyroid patients. Endocr Pract. 2014; 20: 901-6.

103. Trimboli P, Virili C, Centanni M, Giovanella L. Thyroxine Treatment With Softgel Capsule Formulation: Usefulness in Hypothyroid Patients Without Malabsorption. Front Endocrinol (Lausanne). 2018; 9: 118.

104. Fallahi P, Ferrari SM, Antonelli A. IN PATIENTS WITH SUBCLINICAL HYPOTHYROIDISM WHILE IN THERAPY WITH TABLET L-T4, THE LIQUID L-T4 FORMULATION IS MORE EFFECTIVE IN RESTORING EUTHYROIDISM. Endocr Pract. 2017; 23: 170-4.

105. Duntas LH, Benvenga S. Selenium: an element for life. Endocrine. 2015; 48: 756-75.

106. Köhrle J. Selenium and the thyroid. Curr Opin Endocrinol Diabetes Obes. 2015; 22: 392-401.

107. Avery JC, Hoffmann PR. Selenium, Selenoproteins, and Immunity. Nutrients. $2018 ; 10$.

108. Wu Q, Rayman MP, Lv H, Schomburg L, Cui B, Gao C, et al. Low Population Selenium Status Is Associated With Increased Prevalence of Thyroid Disease. J Clin Endocrinol Metab. 2015; 100: 4037-47.

109. Wichman J, Winther KH, Bonnema SJ, Hegedüs L Selenium Supplementation Significantly Reduces Thyroid Autoantibody Levels in Patients with Chronic Autoimmune Thyroiditis: A Systematic Review and Meta-Analysis. Thyroid : official journal of the American Thyroid Association. 2016; 26: 1681-92.

110. Mantovani G, Isidori AM, Moretti C, Di Dato C, Greco E, Ciolli P, et al. Selenium supplementation in the management of thyroid autoimmunity during pregnancy: results of the "SERENA study", a randomized, double-blind, placebo-controlled trial. Endocrine. 2019; 66: 542-50.

111. Winther $\mathrm{KH}$, Wichman JE, Bonnema SJ, Hegedüs L. Insufficient documentation for clinical efficacy of selenium supplementation in chronic autoimmune thyroiditis, based on a systematic review and meta-analysis. Endocrine. 2017; 55: 376-85

112. Esposito D, Rotondi M, Accardo G, Vallone G, Conzo G, Docimo G, et al. Influence of short-term selenium supplementation on the natural course of Hashimoto's thyroiditis: clinical results of a blinded placebo-controlled randomized prospective trial. J Endocrinol Invest. 2017; 40: 83-9.

113. Mao J, Pop VJ, Bath SC, Vader HL, Redman CWG, Rayman MP. Effect of low-dose selenium on thyroid autoimmunity and thyroid function in UK pregnant women with mild-to-moderate iodine deficiency. European journal of nutrition. 2016; 55: 55-61.

114. Yu L, Zhou L, Xu E, Bi Y, Hu X, Pei X, et al. Levothyroxine monotherapy versus levothyroxine and selenium combination therapy in chronic lymphocytic thyroiditis. J Endocrinol Invest. 2017; 40: 1243-50.

115. Barrington JW, Lindsay P, James D, Smith S, Roberts A. Selenium deficiency and miscarriage: a possible link? Br J Obstet Gynaecol. 1996; 103: 130-2.

116. Barrington JW, Taylor M, Smith S, Bowen-Simpkins P. Selenium and recurrent miscarriage. J Obstet Gynaecol. 1997; 17: 199-200.

117. Zachara BA. Selenium in Complicated Pregnancy. A Review. Adv Clin Chem. 2018; 86: 157-78.

118. Pieczyńska J, Grajeta H. The role of selenium in human conception and pregnancy. J Trace Elem Med Biol. 2015; 29: 31-8. 
119. Pilli T, Cantara S, Schomburg L, Cenci V, Cardinale S, Heid EC, et al. IFNY-Inducible Chemokines Decrease upon Selenomethionine Supplementation in Women with Euthyroid Autoimmune Thyroiditis: Comparison between Two Doses of Selenomethionine $(80$ or $160 \mu \mathrm{g})$ versus Placebo. Eur Thyroid J. 2015; 4: 226-33.

120. Eskes SA, Endert E, Fliers E, Birnie E, Hollenbach B, Schomburg L, et al. Selenite supplementation in euthyroid subjects with thyroid peroxidase antibodies. Clin Endocrinol (Oxf). 2014; 80: 444-51.

121. Thomas JK, Janz DM. Developmental and Persistent Toxicities of Maternally Deposited Selenomethionine in Zebrafish (Danio rerio). Environ Sci Technol. 2015; 49: 10182-9.

122. Rayman MP. Selenium intake, status, and health: a complex relationship. Hormones (Athens). 2020; 19: 9-14.

123. Štefanić $M$, Tokić S. Serum 25-hydoxyvitamin D concentrations in relation to Hashimoto's thyroiditis: a systematic review, meta-analysis and meta-regression of observational studies. Eur J Nutr. 2020; 59: 859-72.

124. Gallo D, Mortara L, Gariboldi MB, Cattaneo SAM, Rosetti S, Gentile L, et al. Immunomodulatory effect of vitamin $\mathrm{D}$ and its potential role in the prevention and treatment of thyroid autoimmunity: a narrative review. J Endocrinol Invest. 2020; 43: 413-29.

125. Chao G, Zhu Y, Fang L. Correlation Between Hashimoto's Thyroiditis-Related Thyroid Hormone Levels and 25-Hydroxyvitamin D. Front Endocrinol (Lausanne). 2020; 11: 4

126. Krysiak R, Kowalcze K, Okopien B. Selenomethionine potentiates the impact of vitamin D on thyroid autoimmunity in euthyroid women with Hashimoto's thyroiditis and low vitamin D status. Pharmacol Rep. 2019; 71: 367-73.

127. Krysiak R, Szkróbka W, Okopień B. The Effect of Vitamin D on Thyroid Autoimmunity in Levothyroxine-Treated Women with Hashimoto's Thyroiditis and Normal Vitamin D Status. Exp Clin Endocrinol Diabetes. 2017; 125: 229-33.

128. Chahardoli R, Saboor-Yaraghi A-A, Amouzegar A, Khalili D, Vakili AZ, Azizi F. Can Supplementation with Vitamin D Modify Thyroid Autoantibodies (Anti-TPO Ab, Anti-Tg Ab) and Thyroid Profile (T3, T4, TSH) in Hashimoto's Thyroiditis? A Double Blind, Randomized Clinical Trial. Hormone and metabolic research $=$ Hormon- und Stoffwechselforschung $=$ Hormones et metabolisme. 2019; 51: 296-301.

129. Sriaroon P, Ballow M. Immunoglobulin Replacement Therapy for Primary Immunodeficiency. Immunol Allergy Clin North Am. 2015; 35: 713-30.

130. Alejandria MM, Lansang MA, Dans LF, Mantaring JB, 3rd. Intravenous immunoglobulin for treating sepsis, severe sepsis and septic shock. Cochrane Database Syst Rev. 2013; 2013: Cd001090.

131. Galeotti C, Kaveri SV, Bayry J. IVIG-mediated effector functions in autoimmune and inflammatory diseases. Int Immunol. 2017; 29: 491-8.

132. Nakane S, Mukaino A, Higuchi O, Watari M, Maeda Y, Yamakawa M, et al. Autoimmune autonomic ganglionopathy: an update on diagnosis and treatment. Expert Rev Neurother. 2018; 18: 953-65.

133. Zuercher AW, Spirig R, Baz Morelli A, Käsermann F. IVIG in autoimmune disease - Potential next generation biologics. Autoimmun Rev. 2016; 15: 781-5.

134. Figueiredo AS, Schumacher A. The T helper type 17/regulatory T cell paradigm in pregnancy. Immunology. 2016; 148: 13-21.

135. Krieg S, Westphal L. Immune Function and Recurrent Pregnancy Loss. Semin Reprod Med. 2015; 33: 305-12.

136. Adib Rad H, Basirat Z, Mostafazadeh A, Faramarzi M, Bijani A, Nouri HR, et al. Evaluation of peripheral blood $\mathrm{NK}$ cell subsets and cytokines in unexplained recurrent miscarriage. J Chin Med Assoc. 2018; 81: 1065-70.

137. Jafarzadeh S, Ahmadi M, Dolati S, Aghebati-Maleki L, Eghbal-Fard S, Kamrani A, et al. Intravenous immunoglobulin G treatment increases live birth rate in women with recurrent miscarriage and modulates regulatory and exhausted regulatory T cells frequency and function. J Cell Biochem. 2019; 120: 5424-34.

138. Christiansen OB, Kolte AM, Krog MC, Nielsen HS, Egerup P. Treatment with intravenous immunoglobulin in patients with recurrent pregnancy loss: An update. J Reprod Immunol. 2019; 133: 37-42.

139. Yamada H, Deguchi M, Maesawa Y, Nakajima Y, Nishino Y, Tanimura K, et al. Medium-dose intravenous immunoglobulin therapy for women with six or more recurrent miscarriages. J Reprod Immunol. 2015; 109: 48-51.

140. Ahmadi M, Aghdam SA, Nouri M, Babaloo Z, Farzadi L, Ghasemzadeh A, et al. Intravenous immunoglobulin (IVIG) treatment modulates peripheral blood Th17 and regulatory $\mathrm{T}$ cells in recurrent miscarriage patients: Non randomized, open-label clinical trial. Immunol Lett. 2017; 192: 12-9.

141. Lee SK, Kim JY, Han AR, Hur SE, Kim CJ, Kim TH, et al. Intravenous Immunoglobulin G Improves Pregnancy Outcome in Women with Recurrent Pregnancy Losses with Cellular Immune Abnormalities. Am J Reprod Immunol. 2016; 75: 59-68

142. Stricker RB, Steinleitner A, Bookoff CN, Weckstein LN, Winger EE. Successful treatment of immunologic abortion with low-dose intravenous immunoglobulin. Fertil Steril. 2000; 73: 536-40.

143. Stricker RB, Winger EE. Update on treatment of immunologic abortion with low-dose intravenous immunoglobulin. Am J Reprod Immunol. 2005; 54: 390-6.

144. Moffett A, Shreeve N. First do no harm: uterine natural killer (NK) cells in assisted reproduction. Hum Reprod. 2015; 30: 1519-25.

145. Wong LF, Porter TF, Scott JR. Immunotherapy for recurrent miscarriage. Cochrane Database Syst Rev. 2014; 2014: Cd000112.

146. Christiansen OB, Christiansen BS, Husth M, Mathiesen O, Lauritsen JG, Grunnet N. Prospective study of anticardiolipin antibodies in immunized and untreated women with recurrent spontaneous abortions. Fertil Steril. 1992; 58: 328-34.

147. Stephenson MD, Dreher K, Houlihan E, Wu V. Prevention of unexplained recurrent spontaneous abortion using intravenous immunoglobulin: a prospective, randomized, double-blinded, placebo-controlled trial. Am J Reprod Immunol. 1998; 39: 82-8.

148. Moffett A, Colucci F. Uterine NK cells: active regulators at the maternal-fetal interface. J Clin Invest. 2014; 124: 1872-9.

149. Sojka DK, Yang L, Yokoyama WM. Uterine Natural Killer Cells. Front Immunol. 2019; 10: 960.

150. Gamliel M, Goldman-Wohl D, Isaacson B, Gur C, Stein N, Yamin R, et al. Trained Memory of Human Uterine NK Cells Enhances Their Function in Subsequent Pregnancies. Immunity. 2018; 48: 951-62.e5.

151. Kwak-Kim JY, Chung-Bang HS, Ng SC, Ntrivalas EI, Mangubat CP, Beaman $\mathrm{KD}$, et al. Increased $\mathrm{T}$ helper 1 cytokine responses by circulating $\mathrm{T}$ cells are present in women with recurrent pregnancy losses and in infertile women with multiple implantation failures after IVF. Hum Reprod. 2003; 18: 767-73.

152. Raghupathy R, Makhseed M, Azizieh F, Omu A, Gupta M, Farhat R. Cytokine production by maternal lymphocytes during normal human pregnancy and in unexplained recurrent spontaneous abortion. Hum Reprod. 2000; 15: 713-8.

153. Luan X, Kang X, Li W, Dong Q. An investigation of the relationship between recurrent spontaneous abortion and memory $\mathrm{T}$ follicular helper cells. Am J Reprod Immunol. 2017; 78.

154. Liu Y, Tang X, Tian J, Zhu C, Peng H, Rui K, et al. Th17/Treg cells imbalance and GITRL profile in patients with Hashimoto's thyroiditis. Int J Mol Sci. 2014; 15: $21674-86$

155. He Y, Sun Q. IFN- $\gamma$ induces upregulation of TNF- $\alpha$, downregulation of MMP-2 and MMP-9 expressions in abortion rat. Eur Rev Med Pharmacol Sci. 2018; 22: 4762-7.

156. Lu Q, Luo X, Mao C, Zheng T, Liu B, Dong X, et al. Caveolin-1 regulates autophagy activity in thyroid follicular cells and is involved in Hashimoto's thyroiditis disease. Endocr J. 2018; 65: 893-901.

157. Harman E, Karadeniz M, Avci CB, Zengi A, Erdogan M, Yalcin M, et al. Miscarriage, and TNF-alpha and osteopontin relationship in women patients with Hashimoto's thyroiditis. Gynecol Endocrinol. 2012; 28: 830-3.

158. Dong J, Li J, Zhou G, Peng Z, Li J, Lin S, et al. No Association between TNF-a -308G/A Polymorphism and Idiopathic Recurrent Miscarriage: A Systematic Review with Meta-Analysis and Trial Sequential Analysis. PLoS One. 2016; 11: e0166892.

159. Bilotas MA, Olivares CN, Ricci AG, Baston JI, Bengochea TS, Meresman GF, et al. Interplay between Endometriosis and Pregnancy in a Mouse Model. PLoS One. 2015; 10: e0124900.

160. Khan FA, Al-Jameil N, Khan MF, Al-Rashid M, Tabassum H. Thyroid dysfunction: an autoimmune aspect. Int J Clin Exp Med. 2015; 8: 6677-81.

161. Blois SM, Freitag N, Tirado-González I, Cheng SB, Heimesaat MM, Bereswill $\mathrm{S}$, et al. NK cell-derived IL-10 is critical for DC-NK cell dialogue at the maternal-fetal interface. Sci Rep. 2017; 7: 2189.

162. Gerenova J, Manolova I, Stanilova S. SERUM LEVELS OF INTERLEUKIN - 23 AND INTERLEUKIN - 17 IN HASHIMOTO'S THYROIDITIS. Acta Endocrinol (Buchar). 2019; 5: 74-9.

163. Kaminski VL, Ellwanger JH, Matte MCC, Savaris RF, Vianna P, Chies JAB. IL-17 blood levels increase in healthy pregnancy but not in spontaneous abortion. Mol Biol Rep. 2018; 45: 1565-8

164. $\mathrm{Xu} \mathrm{WM}$, Xiao $\mathrm{ZN}$, Wang $\mathrm{XB}$, Huang Y. IL-17 Induces Fetal Loss in a $\mathrm{CBA} / \mathrm{J} \times \mathrm{BALB} / \mathrm{c}$ Mouse Model, and an Anti-IL-17 Antibody Prevents Fetal Loss in a CBA/J×DBA/2 Mouse Model. Am J Reprod Immunol. 2016; 75: 51-8.

165. Zhang N, Wang Q, Tian Y, Xiong S, Li G, Xu L. Expressions of IL-17 and TNF- $\alpha$ in patients with Hashimoto's disease combined with thyroid cancer before and after surgery and their relationship with prognosis. Clin Transl Oncol. 2019

166. Fröhlich C, Ehrhardt J, Krüger D, Trojnarska D, Zygmunt M, Muzzio DO. Pregnancy status alters IL-21-mediated effects on murine B lymphocytes. Reproduction. 2020; 159: 351-9.

167. Yoshizaki A, Miyagaki T, DiLillo DJ, Matsushita T, Horikawa M, Kountikov EI, et al. Regulatory B cells control T-cell autoimmunity through IL-21-dependent cognate interactions. Nature. 2012; 491: 264-8.

168. Guan LJ, Wang X, Meng S, Shi LF, Jiang WJ, Xiao L, et al. Increased IL-21/IL-21R expression and its proinflammatory effects in autoimmune thyroid disease. Cytokine. 2015; 72: 160-5.

169. O'Hern Perfetto C, Fan X, Dahl S, Krieg S, Westphal LM, Bunker Lathi R, et al. Expression of interleukin-22 in decidua of patients with early pregnancy and unexplained recurrent pregnancy loss. J Assist Reprod Genet. 2015; 32: 977-84.

170. Gilman-Sachs A, Dambaeva S, Salazar Garcia MD, Hussein Y, Kwak-Kim I, Beaman K. Inflammation induced preterm labor and birth. J Reprod Immunol. 2018; 129: 53-8.

171. Zhang $Z$, Liu $H$, Shi $Y, X u N$, Wang $Y$, Li A, et al. Increased circulating Th22 cells correlated with Th17 cells in patients with severe preeclampsia. Hypertens Pregnancy. 2017; 36: 100-7.

172. Guo $\mathrm{H}$, Peng $\mathrm{D}$, Yang $X G$, Wang $Y, X u B C$, Ni JS, et al. A higher frequency of circulating IL-22(+)CD4(+) T cells in Chinese patients with newly diagnosed Hashimoto's thyroiditis. PLoS One. 2014; 9: e84545.

173. Cai JY, Li MJ. Interleukin 23 regulates the functions of human decidual immune cells during early pregnancy. Biochem Biophys Res Commun. 2016; 469: $340-4$ 
174. Cai J, Li M, Huang Q, Fu X, Wu H. Differences in Cytokine Expression and STAT3 Activation between Healthy Controls and Patients of Unexplained Recurrent Spontaneous Abortion (URSA) during Early Pregnancy. PLoS One. 2016; 11: e0163252.

175. Zheng T, Xu C, Mao C, Mou X, Wu F, Wang X, et al. Increased Interleukin-23 in Hashimoto's Thyroiditis Disease Induces Autophagy Suppression and Reactive Oxygen Species Accumulation. Front Immunol. 2018; 9: 96.

176. Štefanić M, Tokić S, Suver Stević M, Glavaš-Obrovac L. Association of increased eomesodermin, BCL6, and granzyme B expression with major clinical manifestations of Hashimoto's thyroiditis - an observational study. Immunol Invest. 2018; 47: 279-92.

177. Akinci B, Comlekci A, Yener S, Bayraktar F, Demir T, Ozcan MA, et al. Hashimoto's thyroiditis, but not treatment of hypothyroidism, is associated with altered TGF-beta1 levels. Arch Med Res. 2008; 39: 397-401.

178. Darmochwal-Kolarz D, Michalak M, Kolarz B, Przegalinska-Kalamucka M, Bojarska-Junak A, Sliwa D, et al. The Role of Interleukin-17, Interleukin-23, and Transforming Growth Factor- $\beta$ in Pregnancy Complicated by Placental Insufficiency. Biomed Res Int. 2017; 2017: 6904325.

179. Manolova I, Gerenova J, Ivanova M. Serum levels of transforming growth factor- $\beta 1$ (TGF- $\beta 1$ ) in patients with systemic lupus erythematosus and Hashimoto's thyroiditis. Eur Cytokine Netw. 2013; 24: 69-74.

180. Stanilova SA, Gerenova JB, Miteva LD, Manolova IM. The Role of Transforming Growth Factor- $\beta 1$ Gene Polymorphism and Its Serum Levels in Hashimoto's Thyroiditis. Curr Pharm Biotechnol. 2018; 19: 581-9.

181. Vacca P, Pesce S, Greppi M, Fulcheri E, Munari E, Olive D, et al. PD-1 is expressed by and regulates human group 3 innate lymphoid cells in human decidua. Mucosal Immunol. 2019; 12: 624-31.

182. Zhang Y, Ma L, Hu X, Ji J, Mor G, Liao A. The role of the PD-1/PD-L1 axis in macrophage differentiation and function during pregnancy. Hum Reprod. 2019; 34: 25-36.

183. Keller CC, Eikmans M, van der Hoorn MP, Lashley L. Recurrent miscarriages and the association with regulatory T cells; A systematic review. J Reprod Immunol. 2020; 139: 103105.

184. Zhao J, Lin B, Deng H, Zhi X, Li Y, Liu Y, et al. Decreased Expression of TIM-3 on Th17 Cells Associated with Ophthalmopathy in Patients with Graves' Disease. Curr Mol Med. 2018; 18: 83-90.

185. Negro R, Formoso G, Mangieri T, Pezzarossa A, Dazzi D, Hassan H. Levothyroxine treatment in euthyroid pregnant women with autoimmune thyroid disease: effects on obstetrical complications. J Clin Endocrinol Metab. 2006; 91: 2587-91.

186. Iravani AT, Saeedi MM, Pakravesh J, Hamidi S, Abbasi M. Thyroid autoimmunity and recurrent spontaneous abortion in Iran: a case-control study. Endocr Pract. 2008; 14: 458-64. 